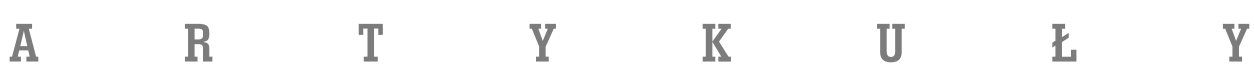

Tadeusz Epsztein

Instytut Historii Polskiej Akademii Nauk

\title{
Wielka własność ziemska w guberni podolskiej na tle Ukrainy Prawobrzeżnej w XIX wieku
}

Zarys treści: Artykuł jest podsumowaniem kilkunastu lat badań, przygotowanych edycji źródłowych i analiz autora dotyczących zmian w sytuacji wielkiej własności ziemskiej na Ukrainie (gubernie kijowska, podolska i wołyńska) w XIX w. Ustalenia dotyczące drugiej połowy tego stulecia zestawia z najnowszymi pracami, prowadzonymi w latach 2013-2016 i obejmującymi gubernię podolską w pierwszej połowie XIX w. Badania zostały przeprowadzone na podstawie źródeł rękopiśmiennych i drukowanych dotąd niewykorzystywanych. Autora interesuje m.in. ewolucja zasięgu wielkiej własności na ziemiach ukraińskich; pozycja polskiego ziemiaństwa; zmiany w elicie wielkiej własności w XIX w.; zależności pomiędzy pozycją majątkową a karierami w samorządzie szlacheckim.

Outline of content: The present article is a summary of several years of research and studies, published sources editions, and analyses made by the author of changes in the ownership structure of great landed property in Ukraine (Guberniyas of Kiev, Podolia, and Volhynia) in the nineteenth century. The author compares the establishments made for the second half of that century with these of the most recent studies, conducted in 2013-2016, for the Guberniya of Podolia in the first half of the nineteenth century. The study is based on handwritten and published primary sources, previously not exploited. The author is interested, among others, in the evolution of extent area of great landed property in Ukraine; the position of Polish landed gentry; changes in the elite of great landed estates owners in the nineteenth century; relationship between a financial position and career within the noble local governments.

Słowa kluczowe: wielka własność ziemska na Ukrainie, ziemiaństwo, Ukraina w XIX w., gubernia kijowska, podolska i wołyńska w XIX w.

Keywords: great landed property in Ukraine, landed gentry, Ukraine in the $19^{\text {th }}$ c., Guberniya of Kiev, of Podolia, and of Volhynia in the $19^{\text {th }} \mathrm{c}$. 
Prowadzone od kilkunastu lat badania nad zmianami w sytuacji wielkiej własności ziemskiej na Ukrainie (gubernie kijowska, podolska i wołyńska) ${ }^{1}$ w XIX w. początkowo przyniosły głównie ustalenia dotyczące drugiej połowy stulecia ${ }^{2}$. Dalsze kwerendy źródłowe pozwoliły rozszerzyć poszukiwania na pierwszą połowę, czyli na okres sprzed reformy włościańskiej. Nie trzeba przypominać znaczenia cezury tzw. wielkiej reformy (1861) nie tylko w dziejach społeczności chłopskiej w Rosji, ale też własności ziemiańskiej. Porównanie zmian w sytuacji wielkiej własności ziemskiej na Ukrainie, jakie zaszły pomiędzy pierwszą a drugą połową stulecia jest głównym celem niniejszego artykułu. Ze względów źródłowych badania ograniczyłem do guberni podolskiej, dla której zachowały się bogatsze materiały, pozwalające na przeprowadzenie powyższej analizy. Punktem wyjścia moich rozważań było pokazanie stanu posiadania wielkiej własności na Podolu w pierwszej połowie XIX w. ${ }^{3}$

Studia porównawcze nad własnością ziemską na terenie Rosji dla okresu przed reformą włościańską są utrudnione dla większych jednostek administracyjnych ze względu na brak odpowiedniej dokumentacji. Statystyka rolna do czasów tzw. wielkiej reformy nie znała w opisie dóbr kryterium powierzchni, dlatego bardzo trudno jest analizować sytuację materialną ziemiaństwa w tych dwóch epokach: do zniesienia poddaństwa i po $1861 \mathrm{r}$. Praktycznie do początku lat sześćdziesiątych podstawą oceny wartości i wielkości nieruchomości ziemskiej w Rosji była liczba chłopów pańszczyźnianych („dusz”) wciągniętych do rejestrów spisowych („rewizyjnych”) i zamieszkałych w dobrach szlacheckich (przypisanych do danych dóbr) ${ }^{4}$.

${ }^{1}$ W wyniku drugiego rozbioru Polski w 1793 r. tereny południowo-wschodnich województw Rzeczypospolitej zostały włączone do Rosji. Na tym obszarze powstały dwie gubernie: bracławska i izjasławska. W skład guberni izasławskiej weszło m.in. województwo podolskie. Po upadku powstania kościuszkowskiego ukazem z 22 maja 1795 r. południowe prowincje rozdzielono na dwa namiestnictwa: podolskie i bracławskie. A w 1796 r. oba namiestnictwa połączono w jedną gubernię podolską, obejmującą znaczną część przedrozbiorowych województw: podolskiego (bez powiatu czerwonogródzkiego) oraz bracławskiego (bez powiatu zwinogródzkiego). Miastem gubernialnym został Kamieniec Podolski. W tym samym czasie gubernia została podzielona na dwanaście powiatów: bałcki, bracławski, hajsyński, jampolski, kamieniecki, latyczowski, lityński, mohylowski, olgopolski, płoskirowski, uszycki i winnicki. Podział ten utrzymał się bez większych zmian do rewolucji $1917 \mathrm{r}$.

2 Zob. T. Epsztein, Przywiazanie szlachty polskiej na Ukrainie do ziemi w XIX i na poczatku XX wieku. Mit czy rzeczywistość?, w: Rosja i Europa Wschodnia. „Imperiologia” stosowana / Russia and Eastern Europe. Applied „Imperiology”, red. A. Nowak, Warszawa-Kraków 2006, s. 400-412; idem, Polska własność ziemska na Ukrainie (gubernia kijowska, podolska i wołyńska) w 1890 roku, Warszawa 2008; idem, Własność ziemska na Ukrainie w 1860 r. w „Statystyce” Andrzeja Grabianki, Warszawa 2013.

3 Prace te przeprowadziłem w latach 2013-2016 w ramach projektu badawczego z zakresu badań podstawowych - Narodowe Centrum Nauki, OPUS, nr 197518, pt. „Wielka własność ziemska w guberni podolskiej w I poł. XIX w.”. Bezpośrednim efektem tego projektu jest moja publikacja książkowa: Wielka własność ziemska w guberni podolskiej w pierwszej połowie XIX wieku, Warszawa 2017.

${ }^{4}$ Dopiero podczas prac przygotowawczych do reformy włościańskiej (1858-1860) zaczęto wykorzystywać kryterium powierzchni do oceny wielkości i charakteru majątków ziemskich; zob. T. Epsztein, Własność ziemska na Ukrainie w 1860 r..., s. 31-33. 
Rejestry spisowe chłopów były uzupełniane w Rosji co kilka lat, dlatego im dłuższy czas upływał od ostatniej rewizji, tym ich rzeczywista wartość informacyjna była mniejsza. W interesującym nas okresie odbyło się kilka rewizji: V, która trwała w latach 1794-1808, VI (1811-1812), VII (1815-1826), VIII (1833-1835), IX (1850) i X (1857-1860)5.

Na podstawie liczby „dusz” wyceniano wartość majątku i obliczano należne podatki. Cena „duszy” zależała od charakteru majątku, jego położenia i wielkości. Na początku XIX w. (1812) wartość pojedynczej duszy wahała się od ponad 90 do ponad $160 \mathrm{rb}$, ale średnia cena na Podolu w tym czasie wynosiła tylko ok. 96 rb $^{6}$. Do „dusz rewizyjnych” nie zaliczano wszystkich chłopów żyjących w dobrach, lecz tylko mężczyzn, przeważnie głowy rodzin. Kobiety, dzieci i pozostałe osoby żyjące pod jednym dachem $\mathrm{z}$ „duszami” nie były w tych rejestrach brane pod uwagę. Część „dusz rewizyjnych" miała gospodarstwa i użytkowała ziemię, inni posiadali wyłącznie ogrody lub tylko chałupy. Najbiedniejsi mieszkali kątem u bogatszych chłopów.

Nie udało się dotąd odszukać kompletnych opisów dóbr dla wszystkich trzech guberni ukraińskich (kijowskiej, podolskiej i wołyńskiej) z okresu poprzedzającego reformę włościańską. Z początku lat pięćdziesiątych zachowało się trochę materiałów, ale o charakterze fragmentarycznym. Do nich można zaliczyć obszerny rękopis zawierający wykazy własności z różnych powiatów ukraińskich, ale poszczególne spisy wykonywane były dla różnych celów, z zastosowaniem odmiennych formularzy ${ }^{7}$. Brakuje w nim także spisów z dwóch powiatów guberni kijowskiej: skwirskiego i wasylkowskiego. Dla niektórych powiatów mamy bardzo bogate opisy, nie tylko z danymi o właścicielach i własnościach, ale także o liczbie, charakterze, wyznaniu służby dworskiej, np. dla powiatu kowelskiego ${ }^{8}$. Jednocześnie lista braków występujących w tym źródle jest długa, do ważniejszych należy pominięcie w wielu powiatach majątków należących do Rosjan. Niekiedy nie ma też imion właścicieli lub wymieniono je sporadycznie. $Z$ reguły podano wyłącznie większe dobra, generalnie powyżej 100 „dusz”. Cennym dodatkiem w tym źródle do niektórych zestawień powiatowych jest informacja o wyznaniu chłopów („dusz rewizyjnych”) zamieszkujących poszczególne dobra. Także z początku lat pięćdziesiątych pochodzi jeszcze inny spis, obejmujący większe (powyżej 100 „dusz”) majątki ziemskie na Ukrainie. Zawiera on wyłącznie dane o nieruchomościach należących do Polaków, nie może więc służyć do analiz porównawczych dla całej wielkiej własności. Cenne są w nim rozbudowane informacje personalne: źródło podaje wiek lub datę urodzin właściciela ziemskiego oraz jego męskich potomków. Przy dzieciach pojawiają się

${ }^{5}$ I.N. Danilevskij, V.V. Kabanov, O.M. Meduševskaâ, M.F. Rumânceva, Istočnikovedenie: Teoriâ. Istoriâ. Metod. Istočniki rossijskoj istorii, Moskva 1998, s. 410.

${ }^{6}$ Dane z kijowskich kontraktów z 1812 r.; zob. Biblioteka Narodowa w Kijowie (Dział Rękopisów) (dalej: BNU), sygn. VI, j. 3901, k. 1; BNU sygn. VI, j. 3915, k. 1.

7 Zob. Centralne Historyczne Archiwum Państwowe Ukrainy w Kijowie (dalej: CDIAU), sygn. f. 442 , o. 805 , d. 368 .

${ }^{8}$ CDIAU, sygn. f. 442 , o. 805 , d. 368 , k. $768-823$. 
też dane o wykształceniu, służbie wojskowej i karierach urzędniczych ${ }^{9}$. Z okresu wcześniejszego dokumentacja jest już zupełnie fragmentaryczna, np. dla guberni kijowskiej zachował się spis szlachty mającej czynne i bierne prawo uczestniczenia w wyborach samorządowych. Dokument podaje nazwę i wielkość majątku' ${ }^{10}$. Wszystkie te cząstkowe materiały nie pozwalają na całościową analizę zmian zachodzących na Ukrainie między początkiem stulecia a epoką reformy włościańskiej, dla której dysponujemy Statystyka Andrzeja Grabianki ${ }^{11}$. Wobec tych problemów badania należało ograniczyć do guberni podolskiej, dla której zachowały się w miarę kompletne źródła z początku lat dwudziestych XIX w. i z 1849 r.

Pierwsze źródło jest wykazem majątków ziemskich, opublikowanym w pracy ks. Wawrzyńca Marczyńskiego ${ }^{12}$. Statystyczne, topograficzne i historyczne opisanie guberni podolskiej należy do najlepszych tego typu opracowań powstałych w pierwszej połowie XIX w. na dawnych ziemiach polskich. Wartość pracy podnosi fakt, że była ona jednocześnie jednym z pierwszych - można powiedzieć wzorcowych opisów „statystycznych” jakie ukazały się w Cesarstwie. Poprzedziła ją niewielka praca Ignacego Emanuela Lachnickiego Statystyka guberni litewsko-grodzieńskiej, wydana w Wilnie w 1817 r., którą Marczyński znał, przygotowując swoją , „statystykę"13. Niewątpliwie też młody kapłan skorzystał z ogólnych wytycznych ogłoszonych przez administrację carską do gromadzenia wiadomości geograficzno-historycznych o poszczególnych regionach Rosji ${ }^{14}$. Instrukcja do zbierania materiałów została wydana w 1812 r., a w 1817 przetłumaczona na język polski i opublikowana przez Uniwersytet Wileński ${ }^{15}$. Prawdopodobnie dokument ten

9 Spisy właścicieli ziemskich mających nie mniej niż 100 „dusz” w guberni kijowskiej, podolskiej i wołyńskiej (1852 r.), zob. CDIAU, sygn. f. 442, o. 1, d. 9860.

10 „Imennyj spisok dworân kijevskoj gubernìi imeûŝih pravo podavat golosa i voobŝe učastvovat v dvorânskih vyborah", 20 XII 1827 g., zob. CDIAU, sygn. f. 533, op. 2, d. 180.

11 T. Epsztein, Własność ziemska na Ukrainie w 1860 r...., s. 22 i n.

12 W. Marczyński, Statystyczne, topograficzne i historyczne opisanie guberni podolskiej, t. 1-3, Wilno 1820-1823 (dalej: Marczyński). Biografię i szczegóły związane z powstaniem pracy ks. Marczyńskiego omawiam szerzej w: T. Epsztein, Wielka własność ziemska..., s. 16-20.

${ }^{13}$ Nie tylko ją znał, ale dobrze przestudiował i wykorzystał, szczególnie we wstępie oraz konstrukcji swojej pracy; zob. I.E. Lachnicki, Statystyka guberni litewsko-grodzieńskiej, Wilno 1817, s. V i [XI]; Marczyński, t. 1, s. 23.

${ }^{14}$ Niektóre opracowania wyszły drukiem, ale ich jakość była bardzo różna, np. w 1836 r. ukazały się jednocześnie opisy dwóch powiatów: rosławskiego (gub. smoleńska) i usmańskiego (gub. tambowska). Pierwsza monografia liczyła tylko 18 stron, druga była znacznie obszerniejsza (ss. 92+4) i staranniej opracowana (np. dołączono do niej 4 tablice statystyczne, w tym wykaz właścicieli ziemskich). Opracowania były opublikowane w „Žurnale Ministerstva vnutrennih del” 1836, nr 10-12 i w osobnym druku: Statističeskoe obozrěnie Roslavl'skogo uězda Smolenskoj gubernii i [N. Bunin], Statističeskoe opisanie Usmanskogo uězda Tambovskoj gubernì, [Sankt' Peterburg' 1836].

${ }^{15}$ Marczyński, t. 1, s. 23. Warto dodać, że efekty tej akcji musiały być mizerne, bo w kolejnych dekadach kontynuowano apele o zbieranie dokumentacji statystycznej, w tej sprawie wydany był m.in. okólnik z odpowiednią instrukcją Ministerstwa Spraw Wewnętrznych z 25 stycznia 1833 r., zob. CDIAU, sygn. f. 442, op. 1, d. 1368, k. 2. 
mógł w 1817 lub 1818 r. trafić do Kamieńca, do kancelarii gubernatora Stanisława Pawłowskiego, od którego instrukcję tę otrzymał Marczyński. Dla naszych zainteresowań najważniejszym fragmentem opracowania ks. Marczyńskiego są wykazy właścicieli ziemskich guberni podolskiej. Do dziś nie udało się odszukać w archiwach ukraińskich dokumentacji dla całej guberni, porównywalnej z materiałem zebranym w Statystycznym opisie guberni podolskiej. Fakt ten z jednej strony poważnie utrudnia pełną ocenę pracy Marczyńskiego, z drugiej zaś podnosi wartość powyższego dzieła, nie można go bowiem zastąpić innym źródłem. Marczyński nie tylko wymienił wszystkich posesorów z podaniem nazw ich majątków (wsi), ale też podał liczbę chłopów („dusz rewizyjnych”) należących do wspomnianych dóbr. Przytoczył również informacje na temat statusu społecznego opisywanych postaci, podając ich tytuły rodowe, posiadane stopnie wojskowe, pełnione przez nich funkcje urzędowe i honorowe. Otrzymaliśmy wiele cennych danych na temat karier miejscowej szlachty posesorskiej, szczególnie jej działalności w samorządzie szlacheckim. Te ostatnie wiadomości są niezwykle cenne, gdyż nadal mało wiemy o aktywności szlachty na tym polu na ziemiach zaboru rosyjskiego. Brakuje pełnej dokumentacji na temat struktury i obsady urzędów samorządowych, także na terenie guberni podolskiej, podobnie jak w innych częściach tzw. Kraju Zachodniego (Litwa, Białoruś i Ukraina).

Drugie źródło wykorzystane do badań prezentowanych w niniejszym opracowaniu pod względem formy i zawartości przypomina po części wykaz właścicieli zestawiony przez Marczyńskiego. Zostało sporządzone przez szlacheckie władze samorządowe na Podolu (Zgromadzenie Szlacheckie w guberni podolskiej) dla administracji rosyjskiej tzw. Kraju Południowo-Zachodniego (gubernie: kijowska, podolska i wołyńska) i zachowało się w postaci rękopiśmiennej w Centralnym Historycznym Archiwum Państwowym Ukrainy w Kijowie ${ }^{16}$. Nie znamy autora rękopisu, ale zwraca uwagę fakt, że cały wykaz został sporządzony przez jedną osobę, praktycznie bez większych poprawek i skreśleń. Inną ręką dopisano tylko w uwagach odesłania do tych samym osób, występujących jako właściciele w różnych powiatach. Przeglądając dokument, możemy się domyślać, że miał on na celu dostarczenie aktualnych informacji na temat sytuacji ekonomicznej i aktywności społecznej szlachty obywatelskiej. Władze carskie od lat trzydziestych (po upadku powstania listopadowego) starały się zmusić ziemiaństwo do wysyłania młodzieży do szkół publicznych i podejmowania służby urzędniczej oraz wojskowej. Nie trudno zdefiniować cel tych teoretycznie słusznych postulatów - chodziło o przyciągnięcie polskich elit do służby państwowej i ich rusyfikację w dalszej perspektywie. Mikołaj I podczas wizytacji na Ukrainie (Wołyń) mógł się osobiście przekonać, rozmawiając z miejscowym ziemiaństwem, że znaczna część młodzieży

16 „Vědomost poměšikam podol'skoj gubernìi”, zob. CDIAU, sygn. f. 442, op. 799, d. 274, cz. 2, k. 12-68. Wykaz znajduje się w poszycie z innymi dokumentami kancelarii generał-gubernatora kijowskiego. 
obywatelskiej nie kształciła się w szkołach publicznych, nie służyła w armii carskiej i nie podejmowała pracy $\mathrm{w}$ administracji ${ }^{17}$. Władze carskie starały się powyższy problem rozwiązać metodami administracyjnymi, narzucając obowiązek służby cywilnej dla kandydatów do samorządu szlacheckiego (na wyższe funkcje, np. marszałków szlachty). Zagrożono wręcz, że ziemianie niepodejmujący służby państwowej i wojskowej będą pozbawieni praw szlacheckich ${ }^{18}$. Jednocześnie władze starały się zebrać informacje na temat stanu wykształcenia i dotychczasowych karier urzędniczych szlachty. Marszałkowie szlachty byli zobowiązani do sporządzania tego typu zestawień.

Mimo sporych podobieństw oba omawiane źródła różnią się między sobą, co $\mathrm{w}$ pewnym stopniu utrudnia porównanie przytaczanych $\mathrm{w}$ nich danych. Największym problemem jest sposób opisania poszczególnych majątków. W wielu wypadkach nie jesteśmy pewni, czy pod daną nazwą miejscowości ukryte są te same dobra. Nasze obawy często potęgowały poważne różnice w liczbie „dusz” przypisanych do danych majątków w badanych przekrojach - nieproporcjonalne do zmian demograficznych, jakie zaszły w ciągu tych 30 lat. Kolejnym problemem był sposób opisania dużych majątków, składających się z wielu nomenklatur. Bardzo często tego typu dobra u Marczyńskiego były rozpisane na poszczególne części z podaniem liczby chłopów przypadających na każdą miejscowość. W spisie z 1849 r. te same majątki miały podaną ogólną liczbę poddanych i wymienione nazwy nomenklatur. Równocześnie zdarzały się przypadki odwrotne. Nie brakuje również nazw miejscowości pojawiających się tylko w jednym źródle.

Przystępując do analizy wykorzystanych źródeł, musimy zadać pytanie o ich wiarygodność i kompletność. Czy praca nad nimi pozwoli opisać badaną grupę i poznać jej problemy i ewolucję? Dla rekonstrukcji stanu materialnego szlachty posesorskiej kapitalne znaczenie ma ustalenie rzeczywistej liczby chłopów należących do prywatnych właścicieli. Czy oba źródła podają prawdziwe dane? Na te pytania nie ma jednoznacznej odpowiedzi, gdyż nie dysponujemy odpowiednim materiałem porównawczym dla interesującego nas okresu. Źródeł jest bardzo mało, a do zachowanych materiałów nie zawsze możemy mieć zaufanie. Najwięcej problemów jest z danymi dla pierwszej ćwierci XIX w., poza Statystyka Marczyńskiego nie mamy innych przekazów drukowanych ani rękopiśmiennych. Jednocześnie liczby dotyczące chłopów pańszczyźnianych podane przez ks. Marczyńskiego w różnych częściach jego pracy różnią się między sobą i nie wiemy, z jakiej przyczyny. Dane sumaryczne umieszczone w tabeli $2 \mathrm{w}$ trzecim tomie Statystyki są znacznie niższe od ogólnej sumy liczb (por. pierwszą i drugą kolumnę w tab. 1) zawartych we wszystkich opisach majątków prywatnych. Prawdopodobnie przy sporządzaniu obu zestawień Marczyński sięgnął do różnych źródeł, stąd niedokładności

17 J. Dunin-Karwicki, Wspomnienia Wołyniaka, Lwów 1897, s. 128-129.

18 D. Beauvois, Trójkąt ukraiński. Szlachta, carat i lud na Wołyniu Podolu i Kijowszczyźnie 17931914, Lublin 2005, s. 446-447. 
Tabela 1. Liczba chłopów („dusz rewizyjnych”) w majątkach prywatnych na Podolu w latach 18201860

\begin{tabular}{|c|c|c|c|c|c|c|}
\hline Powiat & $\begin{array}{c}\text { 1820-1822 } \\
\text { Marczyński, } \\
\text { tab. } 2\end{array}$ & $\begin{array}{l}\text { 1820-1822 } \\
\text { Marczyński, } \\
\text { t. } 1-3\end{array}$ & 1839 r. & $\begin{array}{l}1849 \text { r. } \\
\text { Spis }\end{array}$ & $1849 \mathrm{r}$. & $\begin{array}{l}\text { ok. } 1860 \text { r. } \\
\text { Grabianka }\end{array}$ \\
\hline bałcki & 26148 & 36535 & 40708 & 36075 & 33753 & 36716 \\
\hline bracławski & 37578 & 35737 & 41836 & 33982 & 44489 & 44098 \\
\hline hajsyński & 41726 & 42014 & 42292 & 41279 & 41621 & 45051 \\
\hline jampolski & 37875 & 40720 & 45160 & 44338 & 44721 & 46834 \\
\hline kamieniecki & 33001 & 31940 & 40336 & 38207 & 37333 & 40209 \\
\hline latyczowski & 29310 & 30301 & 24445 & 12683 & 21738 & 21271 \\
\hline lityński & 23691 & 30357 & 38300 & 36561 & 37126 & 36259 \\
\hline mohylowski & 29914 & 26031 & 38175 & 37315 & 38029 & 42862 \\
\hline olgopolski & 40101 & 39001 & 47004 & 45648 & 45112 & 54112 \\
\hline płoskirowski & 40565 & 42711 & 48146 & 45156 & 47789 & 47078 \\
\hline uszycki & 22507 & 27835 & 34733 & 32908 & 33705 & 36799 \\
\hline winnicki & 30628 & 31407 & 36980 & 36084 & 36632 & 38011 \\
\hline Razem & 393044 & 414589 & 478115 & 440236 & 462048 & 489300 \\
\hline
\end{tabular}

Źródło: W. Marczyński, Statystyczne, topograficzne i historyczne opisanie guberni podolskiej, t. 1-3, Wilno 18201823 (dalej: Marczyński, t. 1-3); „Vědomost' o narodonaselenì v’ Podol'skoj Gubernì sostavlena po 1 avgusta 1839 goda”, Biblioteka Narodowa w Kijowie (Dział Rękopisów), sygn. VI 3564, k. 1-2; „Vědomost poměšikam podol'skoj gubernii", Centralne Historyczne Archiwum Państwowe Ukrainy w Kijowie (dalej: CDIAU), sygn. f. 442, o. 799, d. 274, cz. 2, k. 12-68; Voenno-statističeskoe obozrěnie Rossijskoj Imperii, t. 10, č. 2: Podol'skâ̂ guberniâ, Sankt-Peterburg' 1849, tab. 6 (tu w ogólnym podsumowaniu: 459 248); T. Epsztein, Własność ziemska na Ukrainie w 1860 r.w „Statystyce” Andrzeja Grabianki, Warszawa 2013, s. 50, tab. 11; obliczenia własne.

i opuszczenia. Jak wyglądała rzeczywista liczebność „dusz rewizyjnych” na Podolu, które zestawienie jest bliższe prawdy - na te pytania trudno odpowiedzieć. Błędy w obliczeniach mogły wystąpić przy każdym rozwiązaniu. Wydaje się jednak, że bardziej prawdopodobny jest wyższy szacunek, który w mniejszym stopniu odbiega od kolejnych zestawień dotyczących ludności poddanej.

Dla następnych kilkunastu lat nie mamy danych. Kolejne dokumenty pochodzą z końca lat trzydziestych (1838 i 1839 r.), są to dwie rękopiśmienne statystyki zachowane w Bibliotece Narodowej w Kijowie. Pierwsza podaje wyłącznie ogólną liczbę ludności w guberni z podziałem na poszczególne grupy społeczne ${ }^{19}$. Druga jest dla nas ważniejsza, gdyż pokazuje dodatkowo sytuację ludnościową we wszystkich powiatach Podola ${ }^{20}$. Nie wiemy, na podstawie jakich źródeł i w jaki sposób

19 BNU, sygn. VI 3562, „Statističeskaâ vědomost' Podol'skoj Gubernì do Podol'skoj Kazennoj Palaty 1 sentâbrâ 1838 g.", k. 1-2.

20 BNU, sygn. VI 3564, „Vědomost' o narodonaselenìi v' Podol'skoj Gubernìi sostavlena po 1 avgusta 1839 goda", k. 1-2. Zob. tab. 1. 
je opracowano. Oba zestawienia podają zbliżoną liczbę „dusz męskich”, pierwsze 472 457, drugie 478115 osób. Jest interesujące, że statystyki powstały w odstępie roku i zawierają poważne różnice. Dotyczy to zarówno liczebności ludności poddanej (chłopskiej), jak i informacji o innych grupach społecznych. Nie wiemy, czy takie spisy sporządzano regularnie, czy tylko w tym czasie zaistniała taka potrzeba. Nie udało się odnaleźć podobnych zestawień.

Na szczęście mamy materiał porównawczy dla opisanych statystyk. W raporcie generał-gubernatora kijowskiego Dmitrija Bibikowa z 1840 r. znajdziemy informację, że w rękach szlachty ziemiańskiej było na Podolu 934389 chłopów („dusz” obu płci), czyli ok. 467 tys. mężczyzn ${ }^{21}$. Liczba ta $z$ kolei niewiele odbiega od naszego spisu z 1849 r., a jest dodatkowo zbieżna z danymi z ,wojennej” statystyki z 1849 r. (zob. tab. 1). Zestawienia z lat 1840-1849 wskazują, że dane z dokumentów z 1838 i 1839 r. muszą być trochę zawyżone. Trudno inaczej wytłumaczyć zmniejszenie się liczby ludności poddanej w latach czterdziestych czy powtarzające się błędy w różnych, niezależnie wykonanych statystykach urzędowych. Wiarygodność spisu z 1839 r. podważają też poważne dyferencje występujące w obliczeniach dla poszczególnych powiatów $\mathrm{w}$ porównaniu $\mathrm{z}$ innymi zestawieniami $\mathrm{z}$ tego okresu (zob. tab. 1). Także dane dla pozostałych guberni regionu pokazują, że liczba chłopów na Podolu na przełomie lat trzydziestych i czterdziestych musiała być niższa, niż podają dokumenty z 1838 i 1839 r. (zob. tab. 2). Jest to kolejny przykład, z jaką ostrożnością należy odnosić się do ówczesnych danych statystycznych. Dla okresu bezpośrednio poprzedzającego reformę włościańską mamy więcej źródeł i ogólna liczba ludności poddanej w tym czasie nie budzi już poważniejszych wątpliwości. Liczby wynikające ze Statystyki Andrzeja Grabianki mogą być w niewielkim stopniu zaniżone, ale generalnie są porównywalne z danymi występującymi $\mathrm{w}$ innych urzędowych zestawieniach, np. Kartawcow podaje dla guberni podolskiej (504 979) i kijowskiej (546 510) nieco wyższe liczby, a dla wołyńskiej prawie identyczne $(411144)^{22}$.

Dane $\mathrm{z}$ różnych lat dla poszczególnych powiatów pozwalają nam przyjrzeć się dynamice liczebności chłopów w majątkach prywatnych na Podolu. Widzimy, że w większości powiatów nastąpił w pierwszej połowie XIX w. wyraźny wzrost liczby „dusz” (zob. wykres 1). W kilku przypadkach nastąpiło zmniejszenie liczby chłopów ok. 1849 r., a dopiero później wzrost. Tylko w powiecie latyczowskim mamy do czynienia z nietypowym zjawiskiem: w 1849 r. widzimy gwałtowne zmniejszenie liczby chłopów pańszczyźnianych, a w 1860 wzrost, ale liczba końcowa nie przekroczyła poziomu z ok. $1822 \mathrm{r}$. W mniejszej skali miały miejsce wahania liczby chłopów w powiecie lityńskim - po znacznym wzroście w $1849 \mathrm{r}$.

${ }^{21}$ Cyt. za: D. Beauvois, Trójkąt ukraiński..., s. 259.

22 E. Kartavcov, Obrusenie zemlevladěniâ v Ûgo-zapadnom kraĕ, Kìev 1877, s. 19. Dla guberni podolskiej mamy jeszcze informację z 1857 r. - 490 628, zob. Pamâtnaâ knižka Podol'skoj gubernii na 1859 god', Kamenec'-Podol'sk' 1859, s. 111. 
Tabela 2. Liczba chłopów („dusz rewizyjnych”) w majątkach ziemiańskich na Ukrainie w latach $1851-1860$

\begin{tabular}{|l|c|c|c|}
\hline \multicolumn{1}{|c|}{ Gubernia } & $\mathbf{1 8 5 1} \mathbf{~ r .}$ & $\mathbf{1 8 6 0} \mathbf{r .}$ & $\mathbf{1 8 5 1} \mathbf{~ r .}=\mathbf{1 0 0}$ \\
\hline wołyńska & 361786 & 411382 & 114 \\
\hline podolska & 454702 & 489300 & 108 \\
\hline kijowska & 507438 & 536347 & 106 \\
\hline
\end{tabular}

Źródło: P. Keppen, Devâtaâ reviziâ. Izslědovanie o čislě žitelej v’ Rossii v' 1851 gody, Sankt-Peterburg 1857, s. 34, 70, 111; T. Epsztein, Własność ziemska na Ukrainie w 1860 r..., tab. 9, 11, 13.

60000

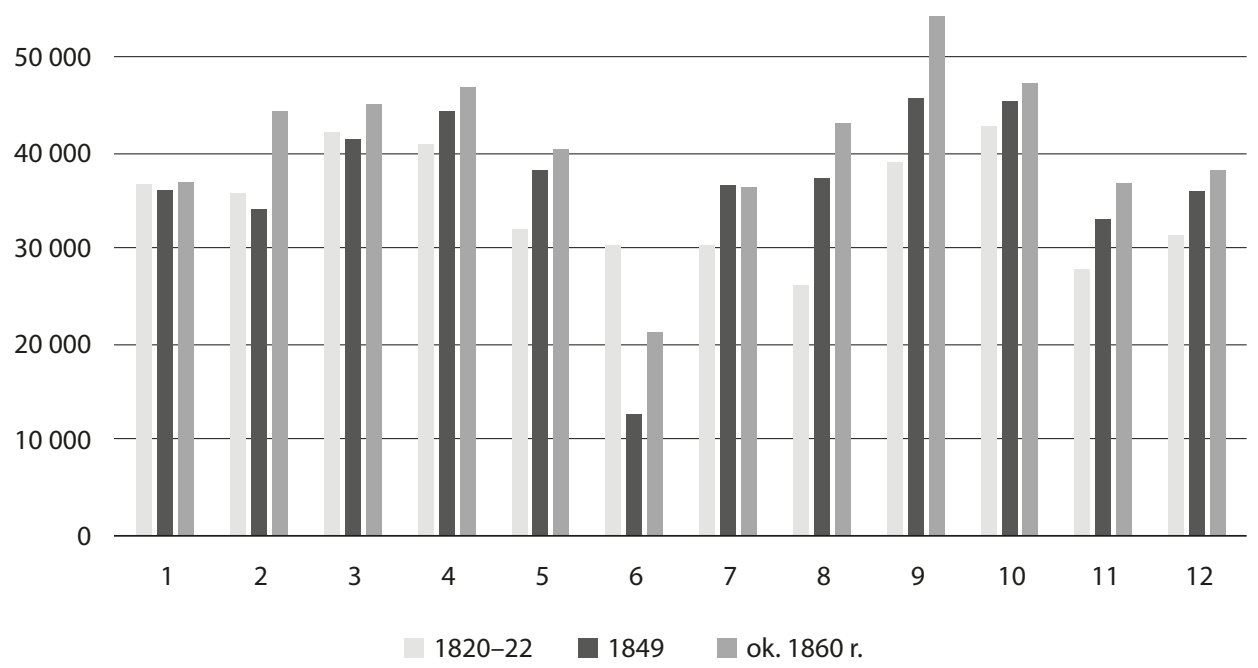

Wykres 1. Zmiany liczby chłopów („dusz rewizyjnych”) w poszczególnych powiatach guberni podolskiej w latach $1820-1860$

Źródło: Marczyński, t. 1-3; „Vědomost poměšikam podol'skoj gubernì”..., k. 12-68; T. Epsztein, Własność ziemska na Ukrainie w 1860 r...., s. 50, tab. 11. Oznaczenia powiatów: 1 - bałcki, 2 - bracławski, 3 - hajsyński, 4 - jampolski, 5 - kamieniecki, 6 - latyczowski, 7 - lityński, 8 - mohylowski, 9 - olgopolski, 10 - płoskirowski, 11 - uszycki, 12 - winnicki.

na początku lat sześćdziesiątych nastąpiło niewielkie załamanie. Ciekawym przypadkiem był również powiat bałcki, gdzie w całym badanym okresie miała miejsce stabilizacja liczebności badanej grupy. Opisane różnice i niekonsekwencje przedstawionych wyliczeń mogą wskazywać na wiele zjawisk. Przede wszystkim mogą świadczyć o ułomności prezentowanych źródeł, o czym już wcześniej wspominałem. Zgromadzone w nich dane mogą być o różnym stopniu kompletności. Nie można też wykluczyć skutków użycia błędnych metod podczas gromadzenia informacji. W przypadku spisu z 1849 r. szczególnie niepokoją obliczenia dla powiatu latyczowskiego, w którym brakuje części majątków. Prawdopodobnie 
Tabela 3. Liczba chłopów („dusz rewizyjnych”) w majątkach marszałków szlachty w 1849 r.

\begin{tabular}{|c|c|c|c|c|}
\hline Lp. & Nazwisko & Imię & \begin{tabular}{|c|}
$\begin{array}{c}\text { Liczba posiadanych } \\
\text { chłopów }\end{array}$ \\
\end{tabular} & $\begin{array}{c}\text { Nazwa powiatu, w którym } \\
\text { był marszałkiem }\end{array}$ \\
\hline 1. & Bernatowicz & Ludwik & 471 & latyczowski \\
\hline 2. & Borejko & Pius & 1124 & lityński \\
\hline 3. & Borkowski Dunin- & Kalikst & 890 & płoskirowski \\
\hline 4. & Borowicki & Hipolit & 170 & wasylkowski \\
\hline 5. & Bratkowski & Kasper & 391 & płoskirowski \\
\hline 6. & Brzozowski & Karol & 3608 & olgopolski \\
\hline 7. & Brzozowski & Piotr & 1781 & olgopolski \\
\hline 8. & Chlebowski & Kajetan & 354 & latyczowski \\
\hline 9. & Chwalibóg & Prosper & 273 & płoskirowski \\
\hline 10. & Czacki & Aleksander & 927 & mohylowski \\
\hline 11. & Czarkowski & Antoni & 450 & latyczowski \\
\hline 12. & Czarnowski & Alojzy & 1454 & hajsyński \\
\hline 13. & Czepielowski & Leon & 815 & hajsyński \\
\hline 14. & Czetwertyński & Borys & 602 & jampolski \\
\hline 15. & Dembowski & Konstanty & 820 & latyczowski \\
\hline 16. & Domaniewski & Wiktor & 281 & lityński \\
\hline 17. & Drzewiecki & Józef & 476 & hajsyński \\
\hline 18. & Dzierżek & Adam & 469 & mohylowski \\
\hline 19. & Giżycki & Jan Nepomucen & 623 & żytomierski (gub. wołyńska) \\
\hline 20. & Iżycki & Mateusz & 2776 & uszycki \\
\hline 21. & Jaroszyński & Antoni & 1000 & jampolski \\
\hline 22. & Jaroszyński & Henryk & 4746 & winnicki \\
\hline 23. & Jaroszyński & Franciszek & 1813 & bracławski \\
\hline 24. & Jasieński & Florian & 307 & humański \\
\hline 25. & Juriewicz & Stanisław & 7819 & olgopolski \\
\hline 26. & Jurkowski & Felicjan & 2130 & winnicki \\
\hline 27. & Kalm & Mikołaj & 862 & olgopolski \\
\hline 28. & Klityński & Jan & 107 & winnicki \\
\hline 29. & Komar & Aleksander & 2819 & kamieniecki \\
\hline 30. & Kosielski & Ludwik & 407 & latyczowski \\
\hline 31. & Krassowski & Pius & 1150 & mohylowski \\
\hline 32. & Krassowski & Józef & 725 & mohylowski i lityński \\
\hline 33. & Krassowski & Henryk & 304 & mohylowski \\
\hline 34. & Krassowski & Franciszek & 463 & mohylowski \\
\hline 35. & Kumanowski & Jerzy & 195 & uszycki \\
\hline 36. & Ługowy & Jan & 317 & latyczowski \\
\hline
\end{tabular}




\begin{tabular}{|c|c|c|c|c|}
\hline Lp. & Nazwisko & Imię & \begin{tabular}{|c|}
$\begin{array}{c}\text { Liczba posiadanych } \\
\text { chłopów }\end{array}$ \\
\end{tabular} & $\begin{array}{c}\text { Nazwa powiatu, w którym } \\
\text { byl marszałkiem }\end{array}$ \\
\hline 37. & Makowiecki & Narcyz & 1447 & uszycki \\
\hline 38. & Mańkowski & Wacław & 448 & jampolski \\
\hline 39. & Mazaraki & Jan & 772 & lityński \\
\hline 40. & Mazaraki & Wincenty & 399 & machnowiecki (gub. kijowska) \\
\hline 41. & Orłowski & Adam & 2536 & płoskirowski \\
\hline 42. & Prolewicz & Alojzy & 222 & olgopolski \\
\hline 43. & Przesmycki & Jan & 504 & bracławski \\
\hline 44. & Przezdziecki & Konstanty & 4955 & $\begin{array}{l}\text { marszałek szlachty gub. } \\
\text { podolskiej }\end{array}$ \\
\hline 45. & Przezdziecki & Karol & 100 & płoskirowski \\
\hline 46. & Rakowski & Cyprian & 428 & bracławski \\
\hline 47. & Reizner & Antoni & 135 & winnicki \\
\hline 48. & Romanowski & Stefan & 327 & lityński \\
\hline 49. & Różycki & Julian & 233 & bałcki \\
\hline 50. & Russanowski & Aleksander & 1433 & kamieniecki \\
\hline 51. & \begin{tabular}{|l|} 
Sarnecki \\
\end{tabular} & Tadeusz & 511 & kamieniecki \\
\hline 52. & Sarnecki & Wincenty & 1233 & lityński \\
\hline 53. & Sobański & Piotr & 940 & jampolski \\
\hline 54. & Sobieszczański & Ignacy & 1251 & winnicki \\
\hline 55. & Stadnicki & Ksawery & 4219 & uszycki \\
\hline 56. & Starzyński & Edward & 3078 & olgopolski \\
\hline 57. & Stempowski & Ignacy & 757 & zasławski (gub. wołyńska) \\
\hline 58. & Szydłowski & Adolf & 265 & uszycki \\
\hline 59. & Trzeciak & Michał & 391 & lityński \\
\hline 60. & Wołodkowicz & Hipolit & 568 & hajsyński \\
\hline 61. & Żaboklicki & Feliks & 174 & bracławski \\
\hline \multirow[t]{2}{*}{62.} & Żeromski & Jan & 628 & zwiahelski (gub. wołyńska) \\
\hline & Razem & & 71873 & \\
\hline
\end{tabular}

Źródło: „Vědomost poměšikam podol’skoj gubernì”..., k. 12-68; obliczenia własne.

za niepełny obraz tego powiatu w spisie z 1849 r. odpowiada pominięcie m.in. majątków Adama Czartoryskiego, skonfiskowanych po powstaniu listopadowym. W samym powiecie latyczowskim Czartoryski po 1831 r. utracił 10656 „dusz”.

W mniejszej skali widoczne są pomyłki w obliczeniach dotyczących innych powiatów. Niewielkie dysproporcje mogą być rezultatem pominięcia lub błędnego dopisania jednego lub dwóch majątków. Czasami brak w ewidencji jednej wsi pociągał za sobą ubytek kilkuset chłopów. Opisane braki i błędy nie mają 
istotnego wpływu na ogólny obraz zbiorowości. W sumie wydaje się, że Statystyka Marczyńskiego, tak jak i spis z 1849 r., podaje w miarę rzeczywistą liczbę „dusz rewizyjnych”. Oba wykazy rejestrują także znaczną większość istniejących majątków ziemskich w podanych przedziałach czasowych ${ }^{23}$.

Wahania w populacji ludności poddanej mogą wynikać z ogólnego przyrostu ludności, ale też z powiększenia się zasięgu dóbr lub zmian ich stanu prawnego. Pewien przyrost obszaru dóbr miał miejsce na początku XIX w., kiedy niektóre dobra skarbowe (o różnym pochodzeniu) były sprzedawane osobom prywatnym, także Polakom. Nie było to zjawisko masowe i nie mogło mieć większego wpływu na ogólny bilans stanu własności. Większe znaczenie mogły mieć konfiskaty po powstaniu listopadowym. Wystarczy wziąć pod uwagę wspomniane już majątki Adama Czartoryskiego na Podolu, obejmujące tysiące chłopów (14 886). Dobra skonfiskowane ks. Adamowi zostały włączone w większości do dóbr skarbowych, czyli nie zasiliły własności prywatnej. Trzeba jednak pamiętać, że proces przejmowania majątków skonfiskowanych po powstaniu listopadowym niekiedy trwał długie dziesięciolecia. Niektóre dobra pozostawały w stanie zawieszenia do połowy XIX w. Jednocześnie część majątków wymienionych w ukazach po powstaniu z różnych powodów nie została ostatecznie Polakom odebrana ${ }^{24}$.

Opracowanie Marczyńskiego i spis z 1849 r., podobnie jak inne wykazy z tego okresu, często dostarczają informacji o wojskowych i urzędniczych karierach właścicieli ziemskich. Zestawienie danych o majątku i zajmowanych stanowiskach $\mathrm{w}$ administracji i samorządzie oraz posiadanych stopniach wojskowych umożliwia prześledzenie zależności między stanem majątkowym szlachty a jej karierami cywilnymi i wojskowymi. Szczególnie prestiżowym stanowiskiem w samorządzie szlacheckim były funkcje marszałka gubernialnego i powiatowego. Teoretycznie każdy szlachcic mający uprawnienia wyborcze mógł starać się o oba stanowiska, w praktyce dostęp do nich był zarezerwowany dla zamożniejszych ziemian, gdyż zasiadanie na tym urzędzie wiązało się ze znacznymi wydatkami, na które mógł sobie pozwolić tylko bogaty właściciel ziemski. Rotacja na urzędach wybieralnych była różna, zależna od charakteru funkcji. Do 1830 r. regularnie co trzy lata odbywały się wybory nowych urzędników. Po powstaniu listopadowym już były okresy większych przerw między kolejnymi sejmikami. Wtedy także wzrosła presja polityczna na osoby ubiegające się o najwyższe funkcje w samorządzie szlacheckim

${ }^{23}$ Pełny wykaz majątków z obu wymienionych źródeł został opublikowany w: T. Epsztein, Wielka własność ziemska..., s. 45-408.

${ }^{24}$ Przeglądając spis skonfiskowanych majątków w guberni podolskiej po 1831 r., ogłoszony przez Janusza Iwaszkiewicza, widzimy wiele dóbr, które jeszcze w 1849 r. pozostawały w rękach polskich, np. Satanów, Tywrów, Bebechy, Sawrań, Krzywe Jezioro, Obodówka, Krasnosiółka, Babczyńce; zob. J. Iwaszkiewicz, Wykaz dóbr ziemskich skonfiskowanych przez rządy zaborcze w latach 1773-1867, Warszawa 1929, s. 40-41; podobne wątpliwości budzi wykaz opracowany przez Józefa Kaczkowskiego, Konfiskaty na ziemiach polskich pod zaborem rosyjskim po powstaniach roku 1831 i 1863, Warszawa 1918, s. 362. 
- marszałków. Nawet wybrani marszałkowie nie zawsze byli zatwierdzani przez władze rosyjskie. Jakikolwiek cień „nieprawomyślności” uniemożliwiał objęcie tej funkcji. W badanym okresie było tylko dwóch marszałków gubernialnych na Podolu: Konstanty Przezdziecki (1820-1850) i Jan Sulatycki (1850-1861), wybieranych przez szlachtę i zatwierdzanych przez władze na kolejne trzylecia. Dużo większa rotacja była widoczna wśród marszałków powiatowych. Świadczy o tym już sam fakt, że jednocześnie było 12 marszałków w guberni podolskiej. Część $\mathrm{z}$ nich piastowała swoje urzędy przez dłuższy czas, ale żaden nie pełnił tej funkcji tak długo jak Przezdziecki. Spis z 1849 r. zarejestrował 56 żyjących marszałków, czyli średnio ok. czterech na jeden powiat. Liczba marszałków z poszczególnych powiatów była następująca: bałcki - 1, bracławski - 4, hajsyński - 4 , jampolski - 4, kamieniecki - 3, latyczowski - 5, lityński - 7, mohylowski - 6, olgopolski - 6, płoskirowski -5 , uszycki -5 , winnicki -5 . Jedynie pojedyncze osoby pełniły funkcje w innych guberniach ukraińskich: wołyńskiej - 3, kijowskiej - 3. Poza powiatem bałckim rozkład marszałków w pozostałych powiatach jest zbliżony i można go uzasadnić dość dużą rotacją tych urzędników. Nie wiadomo, dlaczego tak mało wiemy o obsadzie tego urzędu w Bałckiem.

Średnio w jednym majątku marszałka szlachty mieszkało 1159 chłopów, czyli ponad czterokrotnie więcej niż ogólnie na Podolu (262). Do 20 najzamożniejszych należało prawie 73\% (52 372) wszystkich chłopów w majątkach marszałków szlachty (71 873). Interesująco wyglądają różnice w zamożności marszałków z poszczególnych regionów Podola. Najbogatsi mieszkali w powiecie olgopolskim (średnia: 2895), bogaci w uszyckim (1780), winnickim (1674) i kamienieckim (1588). Najniższa średnia występowała w powiecie latyczowskim (469), już znacznie większa w mohylowskim (673) i lityńskim (688).

Zmieniająca się lista najbogatszych rodzin Podola w pierwszej połowie XIX w. jest odbiciem procesu ewolucji ziemiaństwa tego regionu. Szkoda, że nie możemy uzyskanych obliczeń porównać ze stanem posiadania z końca XVIII w. Miejmy nadzieję, że uda się kiedyś opracować takie zestawienie, które pozwoli lepiej zapoznać się ze zjawiskiem przemian własnościowych na dawnych ziemiach wschodnich Rzeczypospolitej. Trudno bowiem w pełni zrozumieć procesy społeczne i ekonomiczne, jakie tu zachodziły, bez zapoznania się z losem fortun magnackich i wyrastających na nich majątków ziemiańskich. W pierwszej połowie XIX w. erozja dawnych struktur ekonomicznych była daleko posunięta, ale ciągle jeszcze widać było wiele pozostałości z minionego stulecia. Dawne rody magnackie pozostawały $\mathrm{w}$ gronie największych posesorów, ale stopniowo topniały ich majątki, np. Potoccy, mimo utraty znacznej części swoich dóbr, zachowali pierwszą pozycję na Podolu do czasów reformy włościańskiej (zob. tab. 4). Gorzej wyglądała sytuacja Lubomirskich, Mniszchów i Rzewuskich. Te rodziny zniknęły z grona największych posiadaczy ziemskich na Podolu. Nie wiemy, jaki los spotkałby Czartoryskich, gdyby nie powstanie listopadowe. Nie można wykluczyć, że utrzymaliby swoje majątki przez kolejne dziesięciolecia. Już w pierwszej połowie XIX w. z arystokracją 
silnie konkurowało średnie ziemiaństwo, a szczególnie niektóre rodziny. Sukcesy ekonomiczne osiągnęły rody w XVIII w. jeszcze mało znane. Sobańscy już w pierwszej ćwierci XIX w. zajmowali drugie miejsce wśród najbogatszych rodów Podola. Była to rodzina całkiem świeżo wzbogacona, której znaczenie stopniowo rosło, a jej majątek w ciągu 40 lat został prawie podwojony. W drugiej połowie XIX w. Sobańscy wyprzedzili Potockich i stali się najzamożniejszą rodziną w guberni (zob. tab. 5). Niemały sukces był udziałem Jaroszyńskich - podobnie jak Sobańscy, wzbogacili się na przełomie XVIII i XIX w., w 1860 r. byli już na trzecim miejscu na Podolu i swoją pozycję utrzymali w drugiej połowie stulecia. Poważny awans stał się także udziałem innych rodzin, np. Brzozowskich, których majątek urósł w latach 1820-1860 ponad czterokrotnie, czy Sulatyckich, którzy pomnożyli swoje dobra trzykrotnie. Zalescy z kolei swój majątek podwoili. Dużą karierę zrobili także Juriewiczowie i Grocholscy.

Tabela 4. Najzamożniejsze rodziny ziemiańskie na Podolu w pierwszej połowie XIX w.

\begin{tabular}{|c|c|c|c|c|c|c|}
\hline Lp. & 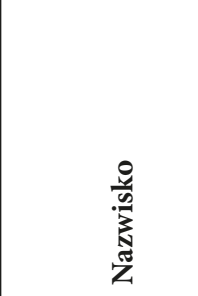 & 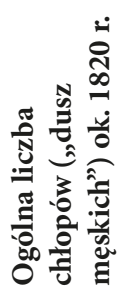 & 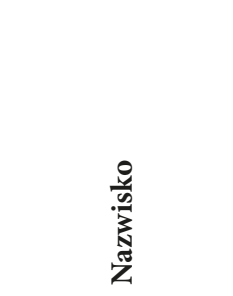 & 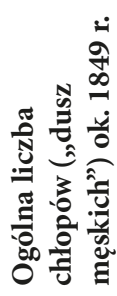 & 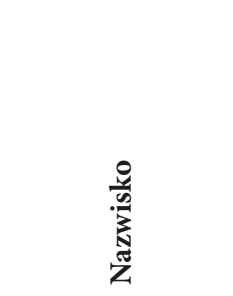 & \\
\hline 1. & Potoccy & 60696 & Potoccy & 48912 & Potoccy & 45954 \\
\hline 2. & Sobańscy & 18031 & Sobańscy & 20363 & Sobańscy & 33529 \\
\hline 3. & Moszyńscy & 16705 & Jaroszyńscy & 13718 & Jaroszyńscy & 17474 \\
\hline 4. & Czartoryscy & 14886 & Szembekowie & 9847 & Szembekowie & 12492 \\
\hline 5. & Jaroszyńscy & 12987 & Orłowscy & 8835 & Brzozowscy & 11376 \\
\hline 6. & Chołoniewscy & 9735 & Juriewiczowie & 7819 & Juriewiczowie & 8260 \\
\hline 7. & Trzeciescy & 7299 & Stadniccy & 7129 & Stadniccy & 7802 \\
\hline 8. & Komarowie & 7220 & Komarowie & 6975 & Grocholscy & 7154 \\
\hline 9. & Czetwertyńscy & 6759 & Grocholscy & 6823 & Wittgensteinowie & 6906 \\
\hline 10. & Rzewuscy & 6708 & Wittgensteinowie & 6238 & Sulatyccy & 6628 \\
\hline 11. & Świeykowscy & 6407 & Przezdzieccy & 5155 & Skibniewscy & 6165 \\
\hline 12. & Przezdzieccy & 6353 & Grabiankowie & 5027 & Jełowiccy & 5803 \\
\hline 13. & Mniszchowie & 6291 & Gaudowiczowie & 4611 & Orłowscy & 5723 \\
\hline 14. & Orłowscy & 5842 & Starzyńscy & 4244 & Zalescy & 5403 \\
\hline 15. & Wirtemberscy & 5743 & Chołoniewscy & 4083 & Gaudowiczowie & 5106 \\
\hline 16. & Lubomirscy & 5605 & Zalescy & 4060 & Starzyńscy & 5057 \\
\hline 17. & Morkowowie & 4872 & Świeykowscy & 4053 & Przezdzieccy & 4873 \\
\hline 18. & Grocholscy & 4798 & Makowieccy & 3910 & Makowieccy & 4572 \\
\hline
\end{tabular}




\begin{tabular}{|c|c|c|c|c|c|c|}
\hline Lp. & 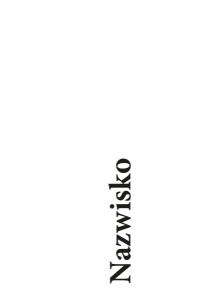 & 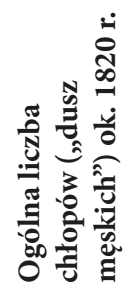 & 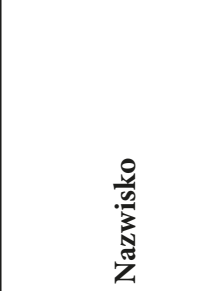 & 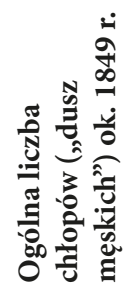 & 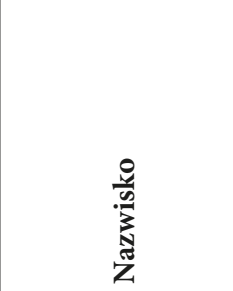 & 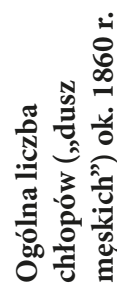 \\
\hline 19. & Grabiankowie & 4354 & Kuszelewowie & 3884 & Chołoniewscy & 4173 \\
\hline 20. & Kuszelewowie & 3562 & Sulatyccy & 3479 & Kuszelewowie & 4043 \\
\hline 21. & Starzyńscy & 3367 & Iwanowscy & 3310 & Komarowie & 4017 \\
\hline 22. & Iwanowscy & 3210 & Krasińscy & 3204 & Grabiankowie & 3951 \\
\hline 23. & Braniccy & 3174 & Sanguszkowie & 3091 & Mańkowscy & 3866 \\
\hline 24. & Lipińscy & 3147 & Skibniewscy & 2792 & Sarneccy & 3649 \\
\hline 25. & Jukowscy & 2877 & Iżyccy & 2776 & Czetwertyńscy & 3396 \\
\hline 26. & Urbanowscy & 2773 & Sarneccy & 2731 & Morkowowie & 3283 \\
\hline 27. & Dzierżkowie & 2712 & Jełowiccy & 2697 & Giżyccy & 3195 \\
\hline 28. & Jełowiccy & 2697 & Borejkowie & 2668 & Russanowscy & 3169 \\
\hline 29. & Borejkowie & 2668 & Krassowscy & 2655 & Czarnieccy & 2939 \\
\hline 30. & Krasińscy & 2640 & Lipińscy & 2611 & Bachmetiewowie & 2844 \\
\hline 31. & Witosławscy & 2501 & Lubomirscy & 2558 & Świeykowscy & 2798 \\
\hline 32. & Dulscy & 2447 & Raciborowscy & 2407 & Iżyccy & 2768 \\
\hline 33. & Brzozowscy & 2421 & Giżyccy & 2396 & Czarnomski & 2616 \\
\hline 34. & Zalescy & 2402 & Mańkowscy & 2300 & Berezowscy & 2451 \\
\hline 35. & Grabowscy & 2051 & Czarnieccy & 2256 & Krassowscy & 2334 \\
\hline 36. & Giżyccy & 2017 & Dywowowie & 2216 & Sobieszczańscy & 2294 \\
\hline 37. & Rakowscy & 1978 & Dzierżkowie & 2209 & Sanguszkowie & 2212 \\
\hline 38. & Bachmetowowie & 1940 & Abamelikowie & 2158 & Raciborowscy & 2098 \\
\hline 39. & Krassowscy & 1910 & Jukowscy & 2130 & Lipińscy & 2086 \\
\hline 40. & Sulatyccy & 1887 & Czarnomski & 1997 & Szczeniowscy & 2058 \\
\hline 41. & Mostowscy & 1861 & Witosławscy & 1933 & Czajkowscy & 2047 \\
\hline 42. & Raciborowscy & 1853 & Trzeciescy & 1911 & Dywowowie & 2010 \\
\hline 43. & Marchoccy & 1847 & Russanowscy & 1878 & Witosławscy & 1962 \\
\hline 44. & Makowieccy & 1830 & Czetwertyńscy & 1873 & Lipkowscy & 1857 \\
\hline 45. & Dzieńkowscy & 1716 & Sadowscy & 1808 & Dorożyńscy & 1847 \\
\hline \multirow[t]{2}{*}{46.} & Dywowowie & 1667 & Radziwiłłowie & 1781 & Iwanowscy & 1842 \\
\hline & Razem & 276446 & & 241511 & & 278082 \\
\hline
\end{tabular}

Źródło: Marczyński, t. 1-3; „Vědomost poměšikam podol’skoj gubernìi”..., k. 12-68; A. Grabianka, „Statističeskìe sveděniâ o poměŝičih' iměniâh' kìevskoj, podol'skoj i volynskoj gubernì...”, St. Petersburg' 1860, rkps, Biblioteka Jagiellońska w Krakowie, sygn. 5985; obliczenia własne. 
Do rozbiorów Rzeczypospolitej większość majątków na Podolu należało do polskich rodzin magnackich i miejscowych rodów szlacheckich. Już na początku XIX w. pojawiła się tu niewielka grupa właścicieli obcych. Największe majątki powstały z darowizn starostw dokonanych jeszcze w końcu XVIII w. Generał Herakliusz hr. Morkow otrzymał starostwo kamienieckie (pow. kamieniecki), a jego brat Arkadiusz Morkow starostwo latyczowskie (pow. latyczowski). Starostwa chreptyjowieckie i wierzbowieckie (pow. uszycki) dostały się Dymitrowi Troszczyńskiemu, chmielnickie - Grzegorzowi hr. Kuszelewowi, uszyckie i bakockie (pow. uszycki) - Sergiuszowi Szeremietiewowi, gubernatorowi wołyńskiemu; lityńskie (pow. lityński) - Andrzejowi Altestiemu, laszkowieckie i kuckie (pow. uszycki) - Stefanowi T. Strekałowowi, gorczyczańskie (pow. uszycki) - Kaczerynowowi, cykowskie (pow. kamieniecki) - Czetwerykowowi ${ }^{25}$. Później część wymienionych dóbr nowi posiadacze odsprzedali miejscowej szlachcie, większość jednak została w rękach rosyjskich.

Listy najzamożniejszych posiadaczy ziemskich na Podolu w różnych okresach XIX w. pozwalają nam zaobserwować, że stopień koncentracji majątku zmniejszył się w badanych dekadach. Około 1820 r. najbogatsze 46 rodzin na Podolu posiadało 67\% ogólnej liczby „dusz”, dla lat 1849 i 1860 ten odsetek wyniósł już 55 i 57\%. Czy niewielki wzrost koncentracji własności w latach pięćdziesiątych XIX w. zapowiadał odwrócenie wcześniejszej tendencji? - trzeba to raczej wykluczyć. $\mathrm{Na}$ początku lat dziewięćdziesiątych tylko wśród polskiego ziemiaństwa do najzamożniejszych 46 rodzin należało 59\% areału ziemi prywatnej będącej w ręku Polaków (tab. 5). Biorąc pod uwagę, że wśród polskich właścicieli był największy odsetek dużych majątków, ogólna koncentracja wielkiej własności w guberni podolskiej musiała być w tym czasie znacznie mniejsza. Ta część polskiej własności ziemskiej stanowiła niespełna 33\% całej ziemi prywatnej. Do wybuchu I wojny światowej proces rozdrobnienia wielkiej własności postąpił jeszcze bardziej.

Tabela 5. Najzamożniejsze polskie rodziny ziemiańskie na Podolu w końcu XIX w.

\begin{tabular}{|c|l|c|}
\hline Lp. & \multicolumn{1}{|c|}{ Nazwisko } & Ogólna powierzchnia majątków (w ha) \\
\hline 1. & Sobańscy & 72196 \\
\hline 2. & Potoccy & 54132 \\
\hline 3. & Jaroszyńscy & 40365 \\
\hline 4. & Juriewiczowie & 30474 \\
\hline 5. & Zalescy & 26525 \\
\hline 6. & Sulatyccy & 23352 \\
\hline 7. & Brzozowscy & 22656 \\
\hline 8. & Stadniccy & 18342 \\
\hline 9. & Rodokonakowie (Barszczewscy) & 17837 \\
\hline 10. & Grocholscy & 17150 \\
\hline
\end{tabular}

25 Słownik geograficzny Królestwa Polskiego i innych krajów słowiańskich, red. B. Chlebowski, W. Walewski, t. 8, Warszawa 1887, s. 458. 


\begin{tabular}{|c|c|c|}
\hline Lp. & Nazwisko & Ogólna powierzchnia majątków (w ha) \\
\hline 11. & Starzyńscy & 16326 \\
\hline 12. & Mańkowscy & 15448 \\
\hline 13. & Orłowscy & 15171 \\
\hline 14. & Chołoniewscy & 15095 \\
\hline 15. & Skibniewscy & 14335 \\
\hline 16. & Jełowiccy & 13902 \\
\hline 17. & Russanowscy & 12871 \\
\hline 18. & Lipkowscy & 9665 \\
\hline 19. & Giżyccy & 9271 \\
\hline 20. & Tyszkiewiczowie & 8929 \\
\hline 21. & Sadowscy & 8880 \\
\hline 22. & Orzechowscy & 7885 \\
\hline 23. & Chełmińscy & 7753 \\
\hline 24. & Raciborowscy & 7652 \\
\hline 25. & Przezdzieccy & 7460 \\
\hline 26. & Kosielscy & 7223 \\
\hline 27. & Makowieccy & 7005 \\
\hline 28. & Regulscy & 6512 \\
\hline 29. & Czarnomscy & 6251 \\
\hline 30. & Morawscy & 6172 \\
\hline 31. & Sokołowscy & 5914 \\
\hline 32. & Janiszewscy & 5648 \\
\hline 33. & Czerwińscy & 5447 \\
\hline 34. & Stempowscy & 5334 \\
\hline 35. & Krassowscy & 5313 \\
\hline 36. & Walewscy & 5253 \\
\hline 37. & Zdziechowscy & 5151 \\
\hline 38. & Czarnowscy & 5038 \\
\hline 39. & Rakowscy & 5013 \\
\hline 40. & Żurowscy & 5000 \\
\hline 41. & Iżyccy & 4856 \\
\hline 42. & Czarneccy & 4803 \\
\hline 43. & Szembekowie & 4469 \\
\hline 44. & Markowscy & 4332 \\
\hline 45. & Grabiankowie & 4244 \\
\hline 46. & Mniszkowie & 4088 \\
\hline Razem & & $606738\left(556640 \mathrm{dz} \cdot .^{\mathrm{a})}\right)$ \\
\hline
\end{tabular}

a) dz. - dziesięcina $=1,09$ ha.

Źródło: T. Epsztein, Polska własność ziemska na Ukrainie (gubernia kijowska, podolska i wołyńska) w 1890 roku, Warszawa 2008. 
Ziemia, którą otrzymali chłopi w wyniku reformy z 1861 r. była określana jako „nadziałowa” lub „ukazowa”. Do osobnych kategorii należała ziemia państwowa (skarbowa, tzw. udely), ziemia kościołów i instytucji (zob. tab. 6). Majątki ziemiańskie należały według terminologii rosyjskiej do własności prywatnej, ale także ziemia nabywana na wolnym rynku przez chłopów była częścią ziemi prywatnej. Również majątki towarzystw chłopskich i spółek do niej należały. W statystyce urzędowej te poszczególne kategorie nie zawsze były wydzielane, dlatego porównując pozycję wybranych grup posiadaczy ziemskich musimy mieć świadomość złożoności owych danych. Dodatkowym problem są niedokładności i różnice $\mathrm{w}$ poszczególnych zestawieniach. Jednocześnie różne wydawnictwa podają z różną skrupulatnością dane dotyczące tych samych spraw i lat ${ }^{26}$. Nie zawsze znamy przyczyny takich rozwiązań. Czasami wahania sięgają setek tysięcy dziesięcin w podsumowaniach dotyczących poszczególnych guberni. Jednak, nie mając innych źródeł, musimy próbować wykorzystać istniejące. Ogólny przyrost powierzchni poszczególnych kategorii ziemi w latach 1877-1905 należy wiązać przede wszystkim z większą dokładnością nowszych obliczeń. Szczególnie w przypadku ziemi „nadziałowej” w 1877 r. nie wzięto pod uwagę wszystkich gruntów należących do wsi, pomijając lasy i nieużytki.

Nasze zainteresowania skupimy na ziemi prywatnej, należącej początkowo głównie do szlachty. Składały się na nią majątki, których właściciele w chwili reformy włościańskiej byli posiadaczami tzw. dusz rewizyjnych (chłopów pańszczyźnianych) ${ }^{27}$. Do tej kategorii własności włączono także drobnych posesorów, mających wyłącznie pojedyncze "dusze”, ich majątki z reguły również nie były imponujące, często nie przekraczały kilkudziesięciu dziesięcin. W $1862 \mathrm{r}$. do szlachty należało jeszcze 6180 tys. dz. Z czasem mniejsze posiadłości należące do szlachty były nabywane przez chłopów i mieszczan. W 1876 r. już tylko 5823 tys. dz. było własnością szlachty, w 1905 r. -4882 tys., a w 1911 r. -4501 tys. ${ }^{28}$ Wśród posiadaczy ziemi prywatnej zawsze uprzywilejowaną pozycję zajmowali Polacy, co było prostą konsekwencją szlacheckiego pochodzenia przeważającej części polskich ziemian.

${ }^{26}$ Dane dla 1877 r.: Sbornik' svedenij po evropejskoj Rossii za god' 1882, St. Peterburg' 1884, s. 4-5; dane dla 1905 r.: „Ežegodnik' Rossii” 3, 1906, s. XXVI.

27 Do 1861 r. za właściciela ziemskiego - „dziedzica dóbr”, przeważnie uważano szlachcica, do którego należał przynajmniej jeden chłop, tzw. dusza rewizyjna. Na ową „duszę” składała się często: cała rodzina chłopska, a czasem nawet inne osoby żyjące pod jednym dachem sadyby włościańskiej. W praktyce cała ta zbiorowość była uzależniona od dworu pańskiego, mimo że formalnie poddanym był tylko gospodarz. $\mathrm{Na}$ "duszę” przypadało średnio od kilku do kilkudziesięciu dziesięcin ziemi, dlatego po zniesieniu poddaństwa i oddzieleniu gruntów dworskich od włościańskich niektórym posiadaczom zostało jedynie po kilka czy kilkanaście dziesięcin, gospodarstw, takich jednak w żaden sposób nie można zaliczyć do dóbr ziemiańskich.

28 Zob. Sel'skoe hozâjstvo Rossii v XX veke. Sbornik statistiko-èkonomičeskih svedenij za 1901-1922 g.g., Moskva 1923, s. 60-61. 
Tabela 6. Struktura własności ziemi na Ukrainie w 1877-1905 r. (w tys. dziesięcin)

\begin{tabular}{|l|c|c|c|c|c|c|}
\hline \multirow{2}{*}{ Gubernia } & Rok & \multicolumn{2}{|c|}{ Prywatna } & & $\begin{array}{c}\text { Pozostała (skarbowa, } \\
\text { kościelna, organizacji } \\
\text { społecznych itd.) }\end{array}$ & Razem \\
\cline { 3 - 4 } & & Ogólnie & $\begin{array}{c}\text { W tym } \\
\text { chłopska }\end{array}$ & & Nadział & \\
\hline wołyńska & 1877 & 2725,3 & 19,5 & 2186,7 & 570,7 & 5482,7 \\
& 1887 & 3033,6 & 54,1 & 2412,7 & 707,8 & 6154,1 \\
& 1905 & 2819,9 & 285,1 & 2298,9 & 653,4 & 5772,2 \\
\hline podolska & 1877 & 1670,5 & 17,8 & 1755,5 & 283,9 & 3709,9 \\
& 1887 & 1643,6 & 46,9 & 1761,3 & 306,8 & 3711,7 \\
& 1905 & 1625,8 & 220,4 & 1754,2 & 277,1 & 3657,1 \\
\hline kijowska & 1877 & 1976,0 & 17,4 & 1948,6 & 405,1 & 4329,7 \\
& 1887 & 2060,1 & 35,5 & 2056,9 & 412,0 & 4529,0 \\
& 1905 & 2092,5 & 319,2 & 2106,8 & 424,4 & 4623,7 \\
\hline Razem & 1877 & 6371,8 & 54,7 & 5890,8 & 1259,7 & 13522,3 \\
& 1887 & 6737,3 & 136,5 & 6230,9 & 1426,6 & 14394,8 \\
& 1905 & 6538,2 & 824,7 & 6159,9 & 1354,9 & 14053,0 \\
\hline
\end{tabular}

Źródło: Sel'skoe hozâjstvo Rossii v XX veke. Sbornik statistiko-èkonomičeskih svedenij za 1901-1922 g.g., Moskva 1923, s. 54.

W opisie zmian zachodzących $\mathrm{w}$ sytuacji wielkiej własności na Ukrainie w XIX w. ogromne znaczenie mają kwestie polityczne i narodowo-wyznaniowe. Podziały etniczne w pewnym momencie stały się wygodnym narzędziem dla caratu do realizacji celów politycznych i społecznych w tym regionie. Jeszcze w pierwszej połowie XIX w. rzadko w dokumentach urzędowych pojawiają się informacje na temat wyznania ziemian, a już w ogóle nie ma danych o narodowości. Podział w tym zakresie można przeprowadzić, porównując brzmienie nazwisk lub opierając się na szczegółowych informacjach biograficznych. Wykorzystałem głównie pierwsze narzędzie, zdając sobie sprawę z jego niedoskonałości, starałem się je wspomagać dodatkowymi wiadomościami, zaczerpniętymi z innych materiałów źródłowych. Przeprowadzona dla obu źródeł analiza wskazała, że w badanym okresie nastąpił niewielki wzrost zasięgu własności obcej, głównie rosyjskiej.

Tabela 7. Liczba chłopów („dusz rewizyjnych”) w majątkach nienależących do Polaków na Podolu w latach $1820-1860$

\begin{tabular}{|c|c|c|c|c|c|}
\hline $\begin{array}{c}\text { Liczba } \\
\text { chłopów } \\
\text { ok. 1820 r. }\end{array}$ & $\begin{array}{c}\text { Procent ogólnej } \\
\text { liczby chłopów } \\
\text { w majątkach } \\
\text { prywatnych } \\
\text { ok. 1820 r. }\end{array}$ & $\begin{array}{c}\text { Liczba } \\
\text { chłopów } \\
\text { ok. 1849 r. }\end{array}$ & $\begin{array}{c}\text { Procent ogólnej } \\
\text { liczby chłopów } \\
\text { w majątkach } \\
\text { prywatnych } \\
\text { ok. 1849 r. }\end{array}$ & $\begin{array}{c}\text { Liczba } \\
\text { chłopów } \\
\text { ok. 1860 r. }\end{array}$ & $\begin{array}{c}\text { Procent ogólnej } \\
\text { liczby chłopów } \\
\text { w majątkach } \\
\text { prywatnych } \\
\text { ok. 1860 r. }\end{array}$ \\
\hline 22566 & $5,4 \%$ & 31698 & $7,2 \%$ & 35639 & $7,3 \%$ \\
\hline
\end{tabular}

Źródło: Marczyński, t. 1-3; „Vědomost poměŝikam podol’skoj gubernìi”.., k. 12-68; A. Grabianka, op. cit.; obliczenia własne. 
W stosunku do sytuacji w pozostałych guberniach ukraińskich, na Podolu był najniższy odsetek majątków należących do Rosjan. Przyjmuje się, że ok. 1861 r. własność niepolska wynosiła w guberniach kijowskiej, podolskiej i wołyńskiej ok. 10\% ogółu. Skład narodowościowy wielkiej własności zaczął się gwałtownie zmieniać $\mathrm{w}$ trzech guberniach po powstaniu styczniowym. Również $\mathrm{w}$ tym czasie pojawiło się więcej materiałów pozwalających na selekcję etniczną badanej zbiorowości. Oficjalne dokumenty rosyjskie z różnych przyczyn zaczęły mniejszość polską wyróżniać i oddzielnie opisywać, co dziś ułatwia nasze badania nad jej statusem na Ukrainie ${ }^{29}$. Podziały narodowo-wyznaniowe spotkamy w statystyce i innych dokumentach urzędowych. Dla naszych analiz szczególnie przydatne są wykazy imienne właścicieli ziemskich, pozwalające badać skład etniczny ziemiaństwa Ukrainy. Jeden z takich spisów wykorzystuję również w niniejszym artykule ${ }^{30}$.

W wyniku represji politycznych i zmian ekonomicznych polskie ziemiaństwo na Ukrainie straciło $\mathrm{w}$ drugiej połowie XIX w. ponad 50\% posiadanego wcześniej areału. We wszystkich trzech zaborach stopniowo kurczył się areał wielkiej własności, ale w tych regionach, gdzie sytuacja polityczna była znośniejsza, proces przebiegał wolniej, np. w Galicji obszar dóbr tabularnych zmniejszył się w latach 1852-1912 tylko o niecałe $19 \%^{31}$. Już w Królestwie Polskim w latach 1864-1909 obszar gruntów dworskich stopniał o blisko $27 \%{ }^{32}$. A tam, gdzie nacisk na Polaków był jeszcze większy, np. w Poznańskiem ${ }^{33}$ czy na ziemiach zabranych, straty były poważniejsze. W zaborze rosyjskim proces kurczenia się gruntów należących do polskiego ziemiaństwa nie przebiegał jednolicie. Zdecydowanie sytuacja na ziemiach litewsko-białoruskich układała się lepiej niż na Ukrainie. Według danych z początku XX w. do Polaków w sześciu guberniach północno-zachodnich

29 Trzeba jednak podkreślić, że pierwsze próby selekcji właścicieli ziemskich według kryteriów etnicznych i wyznaniowych zaczęto praktykować w na Ukrainie na wiele lat przez wybuchem powstania styczniowego. Już w końcu lat czterdziestych powstawały osobne wykazy imienne dla ziemian polskich, z zamiarem narzucenia Polakom określonych zarządzeń administracyjnych.

30 T. Epsztein, Polska własność ziemska...

${ }^{31}$ Ogólny obszar wielkiej własności (nazywanej w Galicji własnością tabularną) zmniejszył się od 1852 do 1912 r. z 3322159 ha do 2694124 ha, czyli o 628035 ha (18,9\%), por. J. Rutkowski, Własność tabularna $w$ Galicji według stanu z końcem roku 1912, „Wiadomości Statystyczne o Stosunkach Krajowych" 25, 1918, z. 4, s. 18-19.

${ }^{32}$ W 1864 r. grunty dworskie w Królestwie Polskim obejmowały 5841 tys. ha, w 1894 r. 5015 tys. ha, a w 1909 r. 4268 tys. ha, por. J. Łukasiewicz, O strukturze agrarnej Królestwa Polskiego po uwłaszczeniu, „Przegląd Historyczny” 62, 1971, z. 2, s. 302.

33 W sumie straty polskiego ziemiaństwa w Poznańskiem w XIX w. były jeszcze większe niż na Ukrainie, w 1848 r. do Polaków należało 948 tys. ha (61,1\% ogólnej powierzchni majątków wielkiej własności), w 1911 r. już tylko 541 tys. ha (32\%), zob. W. Molik, Przemiany w strukturze narodowościowej i społecznej wielkich właścicieli ziemskich w Poznańskiem (od końca XVIII do poczatku XX wieku), w: Szlachta i ziemiaństwo polskie oraz niemieckie w Prusach i Niemczech w XVIII-XX w. Materiały z sesji naukowej 22-24 X 1993 w Szczecinie, red. W. Stępiński, Szczecin 1996, s. 170. 
(Kraj Północno-Zachodni) należało jeszcze ponad 60\% ziemi prywatnej34. Beneficjentami ziemi dworskiej było kilka grup społecznych. Największa część przechodziła $\mathrm{w}$ ręce dużych właścicieli ziemskich, ale nie zawsze pochodzenia szlacheckiego. Niektóre majątki nabywała burżuazja - przemysłowcy, zamożni kupcy, prawnicy, lekarze itp. Dużo ziemi parcelowano na mniejsze działki i sprzedawano chłopom. W guberni podolskiej do 1902 r. chłopi nabyli ponad 117 tys. dz., najwięcej rozparcelowano w powiecie bałckim ${ }^{35}$.

Tabela 8. Obszar majątków prywatnych na Ukrainie ok. 1870, 1896 i $1909^{36}$ r. (dane szacunkowe w dziesięcinach)

\begin{tabular}{|l|c|c|c|c|}
\hline \multirow{2}{*}{ Gubernia } & \multirow{2}{*}{ Rok } & \multicolumn{2}{|c|}{ Obszar ogólny majątków prywatnych } & \multirow{2}{*}{ Razem } \\
\cline { 3 - 4 } & & Majątki polskie & Majątki pozostałe & \\
\hline \multirow{2}{*}{ wołyńska } & 1870 & 2868200 & 291900 & 3160100 \\
& 1896 & 1493100 & 1493900 & 2987000 \\
& 1909 & 1350949 & 1669355 & 3020304 \\
\hline podolska & 1870 & 1396100 & 288700 & 1684800 \\
& 1896 & 875100 & 809600 & 1684700 \\
& 1902 & 790031 & 701861 & 1491892 \\
\hline kijowska & 1870 & 1409800 & 618600 & 2028400 \\
& 1896 & 809900 & 1011100 & 1821000 \\
& 1909 & 661054 & 1173687 & 1834741 \\
\hline \multirow{2}{*}{ Razem } & 1870 & 5674100 & 1199200 & 6873300 \\
& 1896 & 3178100 & 3314600 & 6492700 \\
& 1909 & 2802034 & 3544903 & 6346937 \\
\hline
\end{tabular}

Źródło: N. Temirova, Pomisisiki Ukraïni v 1861-1917 rr. Social'no-ekonomična evolûciâ, Donec'k 2003, s. 68, 70; D. Beauvois, Walka o ziemię. Szlachta polska na Ukrainie prawobrzeżnej pomiędzy caratem a ludem ukraińskim 1863-1914, Sejny 1996, s. 62; „Dziennik Kijowski” 1906, nr 97, s. 1; 1909, nr 165, s. 2; nr 166, s. 2; nr 168, s. 2; nr 169, s. 2; nr 170, s. 2; nr 172, s. 2; nr 182, s. 2; nr 211, s. 2; nr 213, s. 3; nr 219, s. 3; nr 223, s. 4; nr 226, s. 4; nr 230, s. 4 ; nr 234, s. 2 ; nr 238, s. 3 ; nr 252 , s. 4 ; nr 255, s. 3 ; obliczenia własne.

Dane zebrane w tabeli 8 pokazują, że w końcu XIX w. tempo kurczenia się własności polskiej na Ukrainie uległo pewnemu wyhamowaniu i było mniejsze, niż w dwóch dekadach wcześniejszych, ale nadal bardzo duże. Niestety nie mamy pełnych danych dla roku 1909 i nie wiemy, w jakim tempie i kierunku ewoluowała w guberni podolskiej własność Polaków w latach 1902-1909 w stosunku do własności rosyjskiej. Natomiast sytuacja w dekadzie wcześniejszej jest bardziej

${ }^{34}$ R. Jurkowski, Ziemiaństwo polskie Kresów Pólnocno-Wschodnich 1864-1904, Warszawa 2001, s. 55.

35 W powiecie bałckim - 35766 dz., bracławskim - 2924, hajsyńskim - 7556, jampolskim - 7851, kamienieckim - 14 407, latyczowskim - 3855, Lityńskim - 11 518, mohylowskim - 3863, olhopolskim - 3221, płoskirowskim - 4070, uszyckim - 12 701, winnickim 9303. Zob. „Dziennik Kijowski" 1906, nr 97, s. 1.

36 Dla guberni podolskiej dane z $1902 \mathrm{r}$. 
oczywista. W ostatnim dziesięcioleciu XIX w. Polacy stracili kolejne pół miliona dziesięcin. Aby lepiej uświadomić sobie, jak postępował proces rozkładu majątku ziemiańskiego na przełomie XIX i XX w., trzeba prześledzić zmiany w poszczególnych powiatach. Najpełniejsze zestawienia mamy dla guberni podolskiej. $\mathrm{Na}$ początku warto zapoznać się z ogólnym stanem własności prywatnej na Podolu w drugiej połowie XIX i na początku XX w. (zob. tab. 9). Wykorzystaliśmy tu dodatkowe zestawienie dla 1913 r. Dotyczy wyłącznie majątków o powierzchni powyżej $100 \mathrm{dz}$., czyli pomija areał mniejszych gospodarstw, występujących w pozostałych statystykach. Z tego powodu ogólne podsumowania dla poszczególnych powiatów i całej guberni są stosunkowo niskie. Wydaje się, że niezależnie od tej okoliczności wyniki zestawienia z 1913 r. pokazują dalsze, poważne kurczenie się wielkiej własności na Ukrainie.

Przyglądając się liczbom dotyczącym poszczególnych powiatów, po raz kolejny widzimy ułomności ówczesnej statystyki. Nieuzasadnione różnice i wahania w areale wielkiej własności nie mogą świadczyć o rzetelności niektórych danych. Największe wątpliwości budzą obliczenia dla $1888 \mathrm{r}$., znacznie podnoszące zarówno obszar ogólny majątków na Podolu, jak również w części powiatów. Podobne zastrzeżenia budzą dane z tegoż roku dla własności polskiej (zob. tab. 10), trudno uwierzyć, że w powiecie latyczowskim w tym czasie było tak mało ziemi należącej do Polaków. Spis z 1890/1891 r. ${ }^{37}$ pokazuje prawie dwukrotnie większy areał, mimo że statystyka ta pominęła część polskich własności. Z drugiej strony nieproporcjonalnie wysoki wynik dla powiatu lityńskiego dodatkowo podważa wiarygodność zestawienia podanego przez Wiktora Guldmana. Polacy w latach 1865-1905 nie mogli w guberniach zachodnich nabywać ziemi ${ }^{38}$, czyli wszelkie przyrosty areału w kolejnych przedziałach czasowych świadczą wyłącznie o nieścisłościach bieżącej statystyki lub wcześniejszej ${ }^{39}$.

Urzędowe informacje o własności ziemskiej dla początku XX w. wymagają kolejnego komentarza. W 1905 r. został ogłoszony spis rolny w Rosji. Pierwszy miał miejsce w 1877, drugi w $1887 \mathrm{r}^{40} \mathrm{~W}$ roku 1905 położono największy nacisk na ustalenie podziału własności w rolnictwie. Przeprowadzone wówczas badania pozwoliły ocenić skalę zmian, jakie zaszły na wsi w minionym ćwierćwieczu. Wobec rosnącej dynamiki procesów społecznych i ekonomicznych na przełomie

37 Zob. T. Epsztein, Polska własność ziemska..., s. 15 i n.

${ }^{38} \mathrm{Z}$ ograniczeń tych wyłączone były niektóre osoby i rodziny, którym po $1865 \mathrm{r}$. pozwolono kupować nieruchomości ziemskie, zob. B.G. Ol'šamovski, Prava po zemlevladěnî̂u v'Zapadnom' Kraĕ, St. Peterburg' 1899, s. 46-49.

39 Praktycznie w żadnej części dawnej Rzeczypospolitej po 1863 r. nie nastąpił wzrost areału ziemi folwarcznej należącej do Polaków. Też ogólny bilans stanu posiadania wielkiej własności w drugiej połowie XIX w. był także ujemny.

40 Spis został ogłoszony 15 lipca 1905 r. i miał zakończyć się 1 stycznia 1906 r., ale do tego czasu nadesłało materiały spisowe tylko pięć guberni. Dalsze materiały spływały do Centralnego Komitetu Statystycznego w 1906 r. Zob. Statistika zemlevladěniâ 1905 g. Svod' dannyh' po 50-ti guberniâm' evropejskoj Rossii, S.-Peterburg' 1907, s. 1 i n. 
Tabela 9. Obszar majątków prywatnych w guberni podolskiej w latach 1876-1913 (w dziesięcinach)

\begin{tabular}{|l|c|c|c|c|}
\hline \multicolumn{1}{|c|}{ Powiat } & $\mathbf{1 8 7 6}$ r. & $\mathbf{1 8 8 8}$ r. & ok. 1902 r. & ok. 1913 r. \\
\hline bałcki & 289064 & 324809 & 272605 & 161359 \\
\hline bracławski & 88509 & 111527 & 88017 & 76905 \\
\hline hajsyński & 121982 & 119258 & 115432 & 85680 \\
\hline jampolski & 141933 & 148390 & 131031 & 94463 \\
\hline kamieniecki & 139339 & 129008 & 98333 & 78442 \\
\hline latyczowski & 82478 & 57209 & 78627 & 85588 \\
\hline lityński & 140716 & 221899 & 112640 & 85469 \\
\hline mohylowski & 116287 & 110594 & 105135 & 117160 \\
\hline olhopolski & 164009 & 152600 & 171926 & 84725 \\
\hline płoskirowski & 112212 & 114219 & 102350 & 84103 \\
\hline uszycki & 118403 & 113544 & 96172 & 97651 \\
\hline winnicki & 129444 & 127824 & 119624 & 112030 \\
\hline Razem & 1644376 & 1730881 & 1491892 & 858 \\
\hline
\end{tabular}

Źródło: E. Kartavcov, Obrusenie zemlevladěnîa v Ûgo-zapadnom kraĕ, Kìev’ 1877, s. 61-62; V.K. Guldman, Spravočnaâ knižka podol'skoj gubernì, Kamenec' Podol'skij 1888, s. 346; idem, Poměstnoe zemlevladěnie v' podol'skoj gubernii, Kamenec' Podol'skij 1903; „Dziennik Kijowski” 1906, nr 97, s. 1; Vec' Ugo-Zapadnyj Kraj. Spravočnaâ i adresnaâ kniga po Kievskoj, Podol'skoj i Volynskoj gubern'âm', red. A.I. Âroševič, Kiev' 1913.

XIX i XX w. obliczenia spisowe szybko stały się nieaktualne i wymagały dalszych badań i modyfikacji. Spis z 1905 r. odniósł się również do stanu polskiej własności. W trzech guberniach ukraińskich wykazał tylko $2306057 \mathrm{dz}$. w posiadaniu Polaków: w guberni wołyńskiej - 1030 927, podolskiej - 638782 i kijowskiej - 636 $348^{41}$. Już współcześnie kwestionowano jego wyniki. Uważano, że przede wszystkim podał zaniżone dane o powierzchni polskich majątków. Władysław Wakar w opracowaniu przygotowanym podczas wojny twierdził, że błąd spisu mógł sięgać nawet do $0,5 \mathrm{mln} \mathrm{dz}$., czyli do Polaków mogło należeć na początku wieku jeszcze ok. 2,8 mln dz. ${ }^{42}$ Aleksander Weryha-Darowski, powołując się na dane rosyjskie z 1911 r., powiększył polski areał do $3 \mathrm{mln}$ dz., w guberni wołyńskiej 1297 000, podolskiej - 861700 i kijowskiej - $858000^{43}$. Najwięcej wątpliwości można tu mieć do obliczeń dotyczących guberni kijowskiej - różnica w stosunku do danych z 1909 r. sięga prawie 200 tys. dz. Taki obszar miały majątki polskie na Kijowszczyźnie kilkanaście lat wcześniej. Podobnie obszar majątków podolskich nie mógł być tak duży, jeżeli przed 1902 r. wynosił tylko 790 tys. dz., a sporo dużych

${ }^{41}$ J. Bartoszewicz, Na Rusi polski stan posiadania (kraj, ludność, ziemia), Kijów 1912, s. 41, 43, 45, 47.

${ }^{42}$ W. Wakar, Rozwój terytorialny narodowości polskiej, cz. 3: Statystyka narodowościowa kresów wschodnich, Kielce 1917, s. 112.

${ }^{43}$ Nie udało się odszukać w rosyjskich materiałach urzędowych danych podanych przez Darowskiego, zob. A. Weryha-Darowski, Kresy ruskie Rzeczypospolitej, Warszawa 1919, s. 11. 
dóbr zostało później sprzedanych ${ }^{44}$. Dyskusja wokół powierzchni polskiej własności ziemskiej na Ukrainie nie została zakończona po publikacji Darowskiego. Daniel Beauvois w Trójkącie ukraińskim podtrzymuje jego ustalenia, uważając, że Polacy do wojny zachowali w trzech guberniach ok. $3 \mathrm{mln} \mathrm{dz}$., nie przedstawia jednak na ten temat nowych dowodów ${ }^{45}$.

Tabela 10. Obszar majątków należących do Polaków w guberni podolskiej w latach 1876-1905 (w dziesięcinach)

\begin{tabular}{|l|r|r|r|r|r|}
\hline \multicolumn{1}{|c|}{ Powiat } & $\mathbf{1 8 7 6} \mathbf{r .}$ & $\mathbf{1 8 8 8} \mathbf{r .}$ & $\mathbf{1 8 9 0 / 9 1}$ & ok. 1902 r. & $\mathbf{1 9 0 5} \mathbf{\text { r. }}$ \\
\hline bałcki & 147229 & 103492 & 116308 & 102567 & 61090 \\
\hline bracławski & 48101 & 42614 & 39987 & 34100 & 32900 \\
\hline hajsyński & 98011 & 79695 & 79029 & 74705 & 64958 \\
\hline jampolski & 111588 & 99871 & 95843 & 92352 & 65286 \\
\hline kamieniecki & 113817 & 96107 & 86875 & 60031 & 52909 \\
\hline latyczowski & 49999 & 23497 & 43546 & 38481 & 31882 \\
\hline lityński & 81410 & 114274 & 74053 & 58209 & 55607 \\
\hline mohylowski & 85595 & 62998 & 62399 & 43546 & 39911 \\
\hline olhopolski & 116682 & 106324 & 107820 & 97414 & 72158 \\
\hline płoskirowski & 96922 & 90423 & 87136 & 70439 & 60489 \\
\hline uszycki & 87582 & 73698 & 79158 & 58789 & 47872 \\
\hline winnicki & 82604 & 75827 & 70524 & 59398 & 51289 \\
\hline Razem & 1119540 & 968820 & 942678 & 790031 & 636351 \\
\hline
\end{tabular}

Źródło: E. Kartavcov, op. cit., s. 61-62; V.K. Guldman, Spravočnaâ knižka..., s. 346; „O čislě iměnìi prinadležaŝih licam polskogo proishoždeniâ v Ûgo-Zapadnom kraě”, CDIAU, sygn. f. 442, o. 611, d. 217; V.K. Guldman, Poměstnoe zemlevladěnie...; „Dziennik Kijowski” 1906, nr 97, s. 1; W. Wakar, Rozwój terytorialny narodowości polskiej, cz. 3: Statystyka narodowościowa kresów wschodnich, Kielce 1917, s. 103.

Skutków wojny Rosji z polskim ziemiaństwem na ziemiach zabranych nie musimy zaliczyć wyłącznie do kategorii strat - gwałtownego zmniejszenia się stanu posiadania w drugiej połowie stulecia. Wydaje się, że na Ukrainie, podobnie jak w Wielkopolsce, prześladowanie ludności polskiej wyzwoliło obok zjawisk negatywnych także pozytywne. Do tych ostatnich możemy zaliczyć niektóre postawy polskiego ziemiaństwa $\mathrm{w}$ trzech guberniach $\mathrm{w}$ okresie popowstaniowym (1863-1905). Badając trwałość własności ziemskiej w różnych regionach dawnej Rzeczypospolitej, zwróciłem uwagę, że ziemiaństwo nie było bardzo przywiązane do swoich siedzib rodowych, majątki zmieniały właścicieli dość często.

44 Sondażowa próba przeprowadzona dla powiatu uszyckiego pokazała, że tylko w tym regionie w latach 1902-1904 wśród najzamożniejszych właścicieli polskich sprzedano ponad 10 tys. dz. Zob. T. Epsztein, Przywiązanie szlachty..., s. 408.

${ }^{45}$ D. Beauvois, Trójkąt ukraiński..., s. 526-527. 
Im dłuższy okres badamy, tym mniejszy był procent siedzib pozostających w rękach tego samego rodu. Wbrew pozorom na częste zmiany nie miały dużego wpływu procesy dziedziczenia. W Królestwie Polskim większość majątków przechodziła w ręce nowych właścicieli drogą umów kupna-sprzedaży ${ }^{46}$. Niektóre posiadłości od początku XIX w. do 1944 r. miały po kilkunastu różnych posesorów, z których niejeden ograniczał swoje władanie majątkiem do kilku lat.

Sytuacja na Ukrainie była pod tym względem nieco inna, szczególnie jeśli ograniczymy okres naszej obserwacji do lat 1865-1905, gdy obowiązywały wymierzone w Polaków represyjne przepisy dotyczące obrotu prywatną ziemią. W tym czasie w powiecie uszyckim na Podolu $22 \%$ majątków utrzymało się w rękach tej samej rodziny. Dla porównania można dodać, że w powiecie mohylowskim ten odsetek wynosił $25 \%{ }^{47}$. W obu wypadkach odsetek wzrasta, gdy dodamy dobra, które przeszły drogą dziedziczenia do dalszych krewnych, noszących inne nazwiska. Dla powiatu mohylowskiego, dla którego mamy na ten temat dokładniejsze dane, procent majątków, które zostały w rękach bliższych lub dalszych krewnych wyniósł 48. W latach 1865-1905 majątki polskie, które zmieniły właściciela, mogły przejść we władanie wyłącznie rodziny dotychczasowego posesora, być przejęte przez Rosjan lub ulec parcelacji. Stąd można teoretycznie przyjąć, że posesje, które w latach 1865-1905 pozostały w rękach polskich, wszystkie powinny znajdować się w posiadaniu członków tych samych rodzin lub rodzin spokrewnionych, czyli podany wyżej odsetek (48\%) określa też procent dóbr, które w ogóle pozostały w rękach polskich do początku XX w. w powiecie mohylowskim - z przebadanych 129 majątków do XX w. pozostały w rękach polskich 63 (49\%). W przypadku uszyckiego, a także innych powiatów, fakt ten nie zawsze można do końca udowodnić, gdyż nie mamy możliwości wykonania tak szczegółowych i dokładnych

46 T. Epsztein, Zasiedziałość ziemiaństwa na pótnocnym Mazowszu w II poł. XIX i XX w., w: Płońsk i Ziemia Płońska w XIX i XX wieku na tle dziejów Mazowsza Pótnocnego, red. nauk. A. Koseski, J. Szczepański, Płońsk 1998, s. 84-90; idem, Zmiany strukturalne i własnościowe wielkiej własności ziemskiej $w$ województwie warszawskim w latach 1921-1939, w: Sesja naukowa na temat „Jak to na Mazowszu" 3 czerwca 1998 roku, Warszawa 1998, s. 53-66; idem, Ziemiaństwo Lubelszczyzny $w$ drugiej połowie XIX i XX wieku, w: Ziemiaństwo na Lubelszczyźnie, oprac. R. Maliszewska, Kozłówka 2001, s. 41-50; idem, Trwałość własności ziemiańskiej w regionie radomskim na tle innych ziem polskich w 2 poł. XIX i w XX wieku, „Studia Ekonomiczno-Społeczne”, Radom 2004, t. 6, s. 73-92; idem, Przywiązanie szlachty..., s. 400-412; idem, Trwałość własności ziemiańskiej na pótnocno-wschodnim Mazowszu na tle innych ziem polskich w II pot. XIX w. i w XX w., w: Przedstawiciele elit prowincjonalnych w XIX i pierwszej połowie XX w. Materialy z II Spotkania Pokoleń w Kręgu Kultury Ziemiańskiej, Drozdowo, 29 sierpnia 2014 r., red. Ł. Lubicz-Łapiński, Drozdowo 2015, s. 9-21 (edycja elektroniczna: http://www.muzeum-drozdowo.pl/images/wydawnictwa_slider/Pokonferencyjne_Przedstawiciele_elit.pdf (dostęp: 17.03.2017).

47 Dla powiatu mohylowskiego obliczenia przeprowadziłem na podstawie pracy Władysława Górskiego (Powiat mohylowski w guberni polskiej, Kraków 1903), w której autor zgromadził informacje na temat większości majątków i właścicieli ziemskich tego powiatu. Na tej podstawie możemy dosyć dokładnie odtworzyć zmiany własnościowe poszczególnych posesji, a także ustalić pokrewieństwa istniejące pomiędzy kolejnymi posesorami. 
badań, przekrojowe wykazy własności przeważnie zbierają dane z różnych lat. Niekiedy nie możemy stwierdzić, czy brak danego majątku w kolejnym wykazie świadczy o jego sprzedaży lub parcelacji, czy o ukryciu go pod inną nazwą. Jednocześnie daty obowiązywania ukazu grudniowego trzeba traktować dość elastycznie. Po 1865 r. dochodziły do skutku transakcje rozpoczęte wcześniej, a niektóre osoby polskiego pochodzenia uzyskały prawo nabywania dóbr ziemskich; były również, szczególnie na początku, różne możliwości obchodzenia przepisów ukazu grudniowego. Gorzej wypadają ustalenia dla dłuższych przedziałów czasowych. W latach 1820-1904 tylko cztery (4\%) posiadłości w powiecie uszyckim utrzymały się w rękach tego samego rodu, a w powiecie mohylowskim w okresie nieco krótszym (1820-1900) było takich majątków 13 (10\%). I w tym przypadku, obejmując badaniem posesje, które przeszły w posiadanie dalszych krewnych drogą dziedziczenia czy koligacji, otrzymamy trochę wyższy wskaźnik trwałości siedzib ziemiańskich $\mathrm{w}$ obu powiatach.

Podobną analizę przeprowadziłem także w oparciu o inne źródła. W celu maksymalnego wydłużenia okresu objętego badaniem wykorzystałem do analizy rejestry $\mathrm{z}$ akt sądowych dotyczących transakcji przypadkowych dóbr leżących w guberni podolskiej, zawartych w latach 1802-1810. Należy dodać, że wspomniane dokumenty zawierają informacje o "kontraktach zastawnych”, czyli o umowach, w których jeden $\mathrm{z}$ kontrahentów nie był formalnym posesorem nieruchomości, ale jednocześnie nie zawsze wiemy, jaki był ostateczny rezultat kontraktu ${ }^{48}$. Wobec tej sytuacji obserwacją objąłem obu uczestników umowy, bo nierzadko zdarzało się, że transakcje „zastawne” kończyły się przejęciem majątku przez wierzycieli. Czasami w „zastawach” brały udział osoby spokrewnione. Z wybranych losowo 60 transakcji dotyczących różnych dóbr na terenie Podola do ok. 1890 r. w rękach tej samej rodziny (identyczne nazwisko) zachowało się tylko pięć majątków (8\%). Znacznie skracając badany okres (do ok. 1860 r.), otrzymamy niewiele lepszy wynik: osiem majątków (13\%).

W sumie ustalenia te dla dłuższych przedziałów czasowych niewiele odbiegają od wyników zbliżonych badań przeprowadzonych dla ziemiaństwa z Królestwa Polskiego. O wyraźnej odmienności postaw ziemiaństwa ukraińskiego możemy mówić tylko dla lat 1865-1905, w okresie wcześniejszym miejscowi posesorzy handlowali ziemią z podobną częstotliwością jak ich bracia w Królestwie Polskim.

Analizując zmiany własnościowe w trzech guberniach ukraińskich, należy brać pod uwagę różne kierunki obserwacji, które umożliwiają bardziej wszechstronne poznanie tego procesu. Jeżeli ogólnie Polacy stracili ok. 50\% pierwotnego areału, zyski strony przeciwnej już nie były tak jednoznaczne. Własność ziemska nienależąca do Polaków zajmowała do początku lat sześćdziesiątych tylko ok. 10\% gruntów

48 Zob. BNU, sygn. VI 3857, „Wiadomość z akt Sądu Głównego Guberni Podolskiej z kontraktów zastawnych w tychże aktach zapisanych...”. Tamże podobne dokumenty: sygn. VI 3850, VI 3849 i VI 3844. 
dworskich. Stąd nawet niewielki jej przyrost dawał bardzo wysokie wskaźniki procentowe. W trzech guberniach ogólny obszar majątków niepolskich zwiększył się w latach 1865-1909 blisko czterokrotnie, ale na Wołyniu ponad sześciokrotnie, a na interesującym nas Podolu tylko niecałe dwuipółkrotnie. Z jednej strony przyrosty te dokonane kosztem własności polskiej były ogromne, z drugiej strony trzeba zaznaczyć, że mimo to Polacy zachowali owe 50\% swojej własności, które nadal stanowiło sporą część ziemi prywatnej (44\%) na Ukrainie. Wydaje się, że oceniając ten bilans, nie należy postrzegać go wyłącznie w kategoriach porażki. Chociaż przedstawiciele polskiego środowiska ziemiańskiego u progu XX w. alarmowali ziomków o topniejącym areale, ale w sumie Polacy nadal dysponowali na Ukrainie ogromnym potencjałem gospodarczym i społecznym, z którym carat liczył się, choć niechętnie.

\title{
Great landed property in the Gubernyia of Podolia against the background of Right-Bank Ukraine in the nineteenth century
}

\begin{abstract}
Initially, several years of research and studies of changes in the ownership structure of great landed property in Ukraine (Guberniyas of Kiev, Podolia, and Volhynia) in the nineteenth century, has borne fruit mainly for the second half of the century. The publications and materials resulting from the research I have used in the present study. Further archival search made it possible for me to include also the first half of the century, that is the period before the peasant reform. Unfortunately, richer primary sources have preserved only for the Gubernia of Podolia, and the fact made me limit the area of my studies. A comparison of extent area of great landed property in Ukraine that occurred between the first and the latter half of the century is the main goal of the present article. The nineteenth century brought about in Ukraine a significant reduction of the great landed property, mainly in the hands of Polish landed gentry, who lost over fifty percent of their lands. The process was the slowest in the Guberniya of Podolia. A significant part of that land was taken over by peasants in the second half of the nineteenth century.
\end{abstract}

Translated by Grażyna Waluga

\section{Большое землевладение в Подольской губернии на фоне Правобережной Украины в XIX в.}

\section{Абстракт}

Исследования изменений в положении большого землевладения в Украине (Киевская, Подольская и Волынская губернии) в XIX в., которые ведутся более десятка лет, изначально принесли результаты, касающиеся главным образом второй половины этого столетия. В данной работе я пользуюсь публикациями и материалами, на основе этих исследований. Дальнейшие исследования источников позволили расширить поиски до первой половины XIX в., то есть периода до Крестьянской реформы. К сожалению, более богатые материалы по этой эпохе сохранились лишь для Подольской губернии, к которой я должен ограничить проведение анализа. Сравнение изменений в площади 
больших землевладений в Украине, каковы произошли между первой и второй половиной столетия - главная цель данной статьи. В Украине XIX столетие принесло серьезное уменьшение ареала больших земельных владений, но прежде всего самый большой ущерб был причинен польским помещикам, которые потеряли почти 50 \% активов. Медленнее всего фольварочная земля уменьшалась в Подольской губернии. Значительную часть помещичьих земель во второй половине XIX в. перешла в собственность крестьян.

Перевод Агнешка Поспишиль

\section{Bibliografia}

\section{Źródła:}

[Bunin N.], Statističeskoe opisanie Usmanskogo uězda Tambovskoj gubernii, [Sankt' Peterburg' 1836].

Dunin-Karwicki J., Wspomnienia Wołyniaka, Lwów 1897.

Epsztein T., Polska własność ziemska na Ukrainie (gubernia kijowska, podolska i wołyńska) w 1890 roku, Warszawa 2008.

Epsztein T., Wielka własność ziemska w guberni podolskiej w pierwszej połowie XIX wieku, Warszawa 2017.

Epsztein T., Własność ziemska na Ukrainie w 1860 r. w „Statystyce” Andrzeja Grabianki, Warszawa 2013.

Guldman V.K., Poměstnoe zemlevladěnie v’ podol'skoj gubernii, Kamenec' Podol'skì 1903.

Guldman V.K., Spravočnaâ knižka podol'skoj gubernii, Kamenec' Podol'skìj 1888.

Kartavcov E., Obrusenie zemlevladènîa v Ûgo-zapadnom kraĕ, Kìev 1877.

Keppen P., Devâtaâ reviziâ. Izslědovanie o čislě žitelej v’ Rossii v’ 1851 gody, Sankt-Peterburg 1857.

Lachnicki I.E., Statystyka guberni litewsko-grodzieńskiej, Wilno 1817.

Marczyński W., Statystyczne, topograficzne i historyczne opisanie guberni podolskiej, t. 1-3, Wilno 1820-1823.

Pamâtnaâ knižka Podol'skoj gubernii na 1859 god', Kamenec'-Podol'sk' 1859.

Rutkowski J., Własność tabularna w Galicji według stanu z końcem roku 1912, „Wiadomości Statystyczne o Stosunkach Krajowych” 25, 1918, z. 4.

Sbornik' svedenij po evropejskoj Rossii za god' 1882, St. Peterburg' 1884.

Sel'skoe hozâjstvo Rossii v XX veke. Sbornik statistiko-èkonomičeskih svedenij za 1901-1922 g.g., Moskva 1923.

Statističeskoe obozrěnie Roslavl'skogo uězda Smolenskoj gubernii, [Sankt' Peterburg' 1836].

Statistika zemlevladěniâ 1905 g. Svod' dannyh' po 50-ti guberniâm' evropejskoj Rossii, S.-Peterburg' 1907

Vec' Ûgo-Zapadnyj Kraj. Spravočnaâ i adresnaâ kniga po Kievskoj, Podol'skoj i Volynskoj gubern'âm', red. A.I. Âroševič, Kìv' 1913.

Voenno-statističeskoe obozrěnìe Rossijskoj Imperii, t. 10, č. 2: Podol’skaâ guberniâ, Sankt-Peterburg' 1849.

\section{Opracowania:}

Bartoszewicz J., Na Rusi polski stan posiadania (kraj, ludność, ziemia), Kijów 1912.

Beauvois D., Trójkąt ukraiński. Szlachta, carat i lud na Wołyniu Podolu i Kijowszczyźnie 17931914, Lublin 2005. 
Beauvois D., Walka o ziemię. Szlachta polska na Ukrainie prawobrzeżnej pomiędzy caratem a ludem ukraińskim 1863-1914, Sejny 1996.

Danilevskij I.N., Kabanov V.V., Meduševskaâ O.M., Rumânceva M.F., Istočnikovedenie: Teoriâ. Istoriâ. Metod. Istočniki rossijskoj istorii, Moskva 1998.

Epsztein T., Przywiązanie szlachty polskiej na Ukrainie do ziemi w XIX i na początku XX wieku. Mit czy rzeczywistość?, w: Rosja i Europa Wschodnia. „Imperiologia” stosowana / Russia and Eastern Europe. Applied „Imperiology”, red. A. Nowak, Warszawa-Kraków 2006, s. $400-412$.

Epsztein T., Trwałość własności ziemiańskiej na pótnocno-wschodnim Mazowszu na tle innych ziem polskich $w$ II poł. XIX w. i $w$ XX w., w: Przedstawiciele elit prowincjonalnych $w$ XIX i pierwszej połowie XX w. Materiały z II Spotkania Pokoleń w Kręgu Kultury Ziemiańskiej, Drozdowo, 29 sierpnia 2014 r., red. Ł. Lubicz-Łapiński, Drozdowo 2015, s. 9-21 (edycja elektroniczna: http://www.muzeumdrozdowo.pl/images/wydawnictwa_slider/Pokonferencyjne_Przedstawiciele_elit.pdf (dostęp: 17.03.2017).

Epsztein T., Trwałość własności ziemiańskiej $w$ regionie radomskim na tle innych ziem polskich w 2 poł. XIX i w XX wieku, „Studia Ekonomiczno-Społeczne”, Radom 2004, t. 6, s. 73-92.

Epsztein T., Zasiedziałość ziemiaństwa na pótnocnym Mazowszu w II poł. XIX i XX w., w: Płońsk i Ziemia Płońska w XIX i XX wieku na tle dziejów Mazowsza Pótnocnego, red. nauk. A. Koseski, J. Szczepański, Płońsk 1998, s. 84-90.

Epsztein T., Ziemiaństwo Lubelszczyzny w drugiej połowie XIX i XX wieku, w: Ziemiaństwo na Lubelszczyźnie, oprac. R. Maliszewska, Kozłówka 2001, s. 41-50.

Epsztein T., Zmiany strukturalne i własnościowe wielkiej własności ziemskiej w województwie warszawskim w latach 1921-1939, w: Sesja naukowa na temat "Jak to na Mazowszu” 3 czerwca 1998 roku, Warszawa 1998, s. 53-66.

Górski W., Powiat mohylowski w guberni polskiej, Kraków 1903.

Iwaszkiewicz J., Wykaz dóbr ziemskich skonfiskowanych przez rządy zaborcze w latach 1773-1867, Warszawa 1929.

Jurkowski R., Ziemiaństwo polskie Kresów Pótnocno-Wschodnich 1864-1904, Warszawa 2001.

Kaczkowski J., Konfiskaty na ziemiach polskich pod zaborem rosyjskim po powstaniach roku 1831 i 1863, Warszawa 1918.

Łukasiewicz J., O strukturze agrarnej Królestwa Polskiego po uwłaszczeniu, „Przegląd Historyczny" 62, 1971, z. 2, s. 295-315.

Molik W., Przemiany w strukturze narodowościowej i społecznej wielkich właścicieli ziemskich w Poznańskiem (od końca XVIII do początku XX wieku), w: Szlachta i ziemiaństwo polskie oraz niemieckie $w$ Prusach $i$ Niemczech $w$ XVIII-XX w. Materiały $z$ sesji naukowej 22-24 X 1993 w Szczecinie, red. W. Stępiński, Szczecin 1996, s. 159-177.

Ol'šamovski B.G., Prava po zemlevladěnî̀ v' Zapadnom' Kraĕ, St. Peterburg' 1899.

Temirova N., Pomišiki Ukraïni v 1861-1917 rr. Social'no-ekonomična evolûciâ, Donec'k 2003.

Wakar W., Rozwój terytorialny narodowości polskiej, cz. 3: Statystyka narodowościowa kresów wschodnich, Kielce 1917.

Weryha-Darowski A., Kresy ruskie Rzeczypospolitej, Warszawa 1919.

Tadeusz Epsztein (ur. 1959), dr hab. prof. IH PAN, zajmuje się m.in. dziejami ziemiaństwa polskiego w XIX i XX w., archiwistyką i edycją źródeł (tadeuszepsztein@o2.pl).

Tadeusz Epsztein (b. 1959), Dr. hab., a professor at the Tadeusz Manteuffel Institute of History, Polish Academy of Sciences; his research interests are, among others, the history of Polish landed gentry in the $19^{\text {th }}$ and $20^{\text {th }}$ century, archivist studies, and edition of primary sources (tadeuszepsztein@o2.pl). 